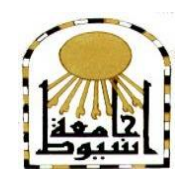

كلية التربية للمفولة المبكرة

إدارة البممث والنشر العلمي (المبلة العلمية)

$=====$

\title{
بيئة الروضة وعلاقتها ببعض مهارات \\ الاستعداد للقراءة لدى طفل الروضة
}

\author{
إعـــــاد \\ د./ إياء الممد هممود كدواني \\ مدرس مناهج الطقل- قسم العلوم التربوية \\ كلية رياض الاطفال- جامعة اسيوط
}

(العدد العاشر - يوليو 9 1 • rم) 
ملخص البحث

هدف البحث الحالي بشكل رئيس إلى التعرف على علاقة بيئة الروضة ببعض

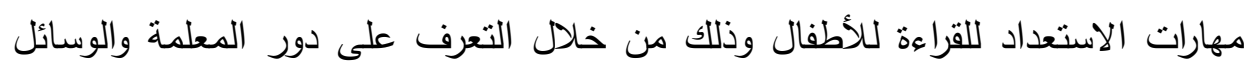
والتجهيزات الصفية وعلاقتها ببعض مهارات الاستعداد للقراءة للأطفال وكذلك التعرف

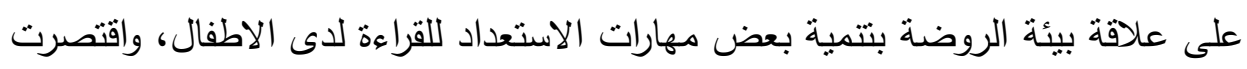

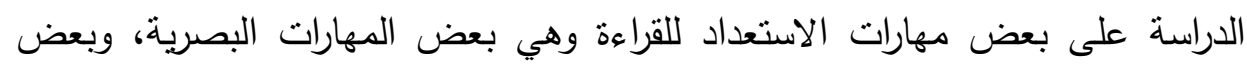

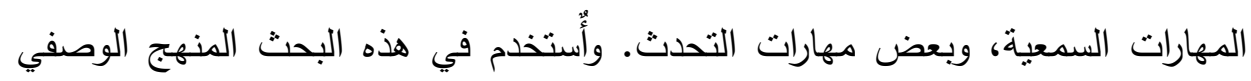

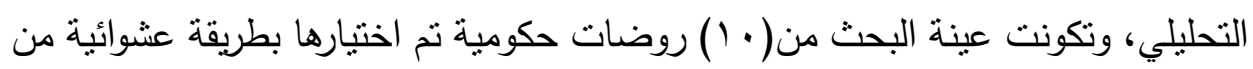

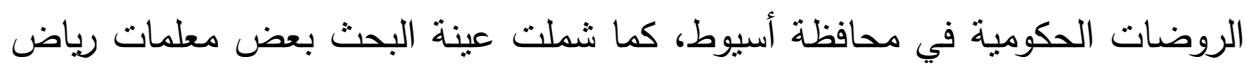
الأطفال والبالغ عددهن (.0 ) معلمة و شملت عينة البحث بعض الاطفال في الفئة

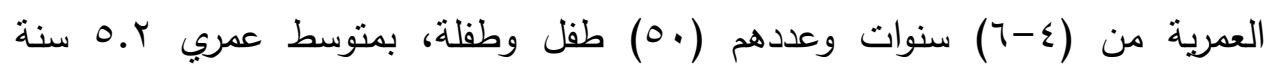

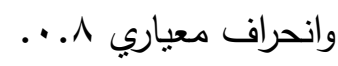

ونت اعداد الأدوات التالية: : - استبانة موجهة لمعلمات رياض الأطفال تهدف إلى معرفة دور المعلمة في استخدام الأنشطة لتتمية بعض مهارات الاستعداد للقراءة

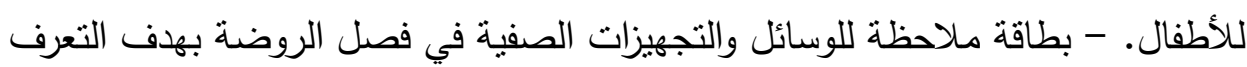
على مدى توافرها. - المقياس المصور لبعض مهارات الاستعداد للقراءة لطفل الروضة. ومن اهم النتائج التي اسفر عنها البحث وجود علاقة ارتباطية موجبة دالة إحصائياً بين

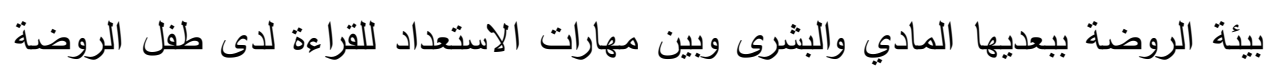
حيث كان معامل الارتباط طردي ودال احصائيا.

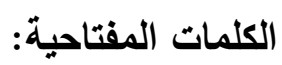
بيئة الروضة -مهارات الاستعداد للقراءة- طفل الروضة 


\title{
The Kindergarten Environment and Its Relation with Some Reading Readiness Skills for Kindergarten Child
}

\begin{abstract}
The main objective of the current research is to identify the relationship of the kindergarten environment with some reading readiness skills for children by identifying the role of the teacher and the instruments and equipment of the classroom and its relation to some reading readiness skills for children, as well as the relationship of the kindergarten environment on developing some reading readiness skills for the children. Reading readiness skills include some visual skills, audio skills, and speaking skills. The research sample consisted of (10) government kindergartens randomly selected from the governmental kindergartens in Assiut Governorate. The sample also included (50) kindergarten teachers. The sample included (50) children in the age category of (4-6) years (Boys and Girls), with an average age of 5.2 years and a standard deviation of 0.08
\end{abstract}

The following tools have been developed:

- A questionnaire for teachers of kindergartens aimed at identifying the role of the teacher in using the activities for developing some reading readiness skills for children.

- An observation card for the instruments and equipment in the classroom to determine it's availability.

- An Illustrated measure of some readiness skills for kindergarten reading.

The most important research results found were a positive correlative relationship between the kindergarten environment with its physical and human dimensions and the reading readiness skills of the kindergarten child where the correlation coefficient was trivial and statistically significant..

Key words:

Kindergarten environment - Reading readiness skills - Kindergarten Child

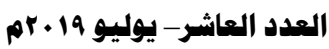




\section{مجلة " دراسات في الطقولة والتربية" - جامعة اسيوط}

\section{مقدمة البحث}

تعتبر مرحلة الطفولة المبكرة من أهم مراحل العمر، وتعد مؤسسات رياض

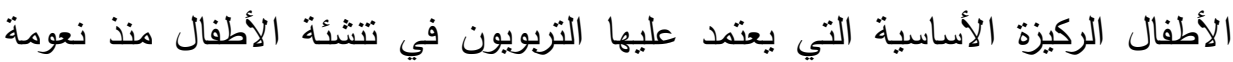

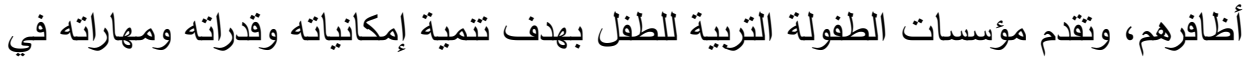
مختلف جوانب النمو، وهي الوسيط الأساسي لارتباط الطفل بالمؤسسات التعليمية في مرحلة النمو النالية، كما أنها تعد بمثابة حلقة وصل بين الطفل والمجتمع الخارجي. كما تعد من أهم المراحل التي يمر بها الإنسان في حياته، نظرًا لما يكون لديه في هذه المرحلة من قابلية شديدة للتأثر بما يحيط به من عوامل مختلفة، تؤثر على نموه بشكل عام، كما تؤثر على ما لديه من خصائص، ومواهب وقدرات بشكل خاص؛ مما يكون له أبعد الأثر في تكوين شخصيته المستقبلية ولأهمبة هذه المرحلة أكد المربون على ضراني ضرورة العناية بها، وعلى ضرورة توفير بيئة ملائمة وسوية للطفل، نساهم في تتشيط قدراته، وتحفيز

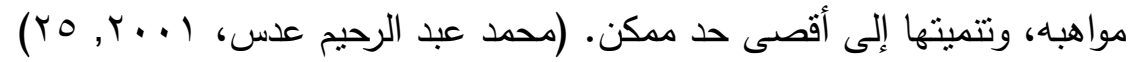

وتسعى رياض الأطفال لتحقيق تلك الأهداف التربوية الثاملة بتهيئة بيئة غنية بالأنشطة والوسائل الموزعة في أركان تعليمية، وهي تستهدف تثتيت الدفاهيم لدى الأطفال، وتتمية حواسهم، وقدراتهم، عن طريق اللعب الحر المحبب للأطفال .

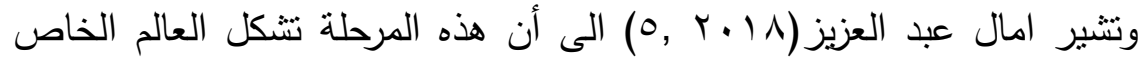
للأطفال بكل ما فيها من خبرات تؤدي الى تتميه جميع جوانب النمو المختلفة لديهم بما فيها النمو المعرفي، الإدراكي، والانفعالي والاجتماعي مما ينمي قدره الطفل على التخيل والابتكار والتفكير غير المحدود،في القرن الحادي والعشرين أصبح الاهتمام بالطفولة المبكرة من أولويات الأهداف التربوية والتعليمية،علي المسنوي الدولي والعربي. ومن هذا المنطلق تتأكد أهمية رياض الأطفال كمؤسسة تربوية، تقوم برعاية

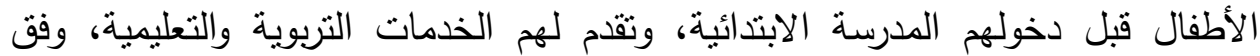

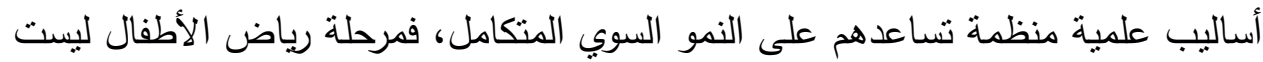
مرحلة للتنريس بقدر ما هي مرحلة للنتمية الثناملة لحواس الطفل، وميوله، واستعداداته، 
وذللك حتى يصل الطفل إلى المرحلة الابتدائية وهو مستعد للتعلم، ولاكتساب الخبرات

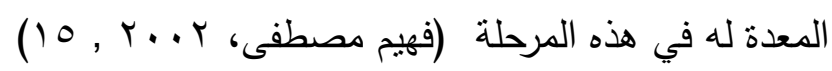
ومن هنا برزت أهية دور رياض الاطفال كبيئة تربوية فاصلة ما بين البيت

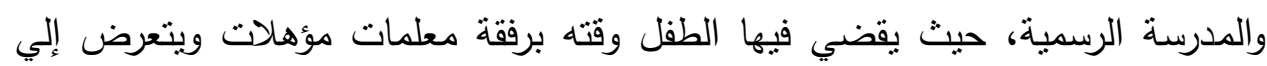
خبرات تربوية هادفة تساعده علي إنضاج شخصيته بشكل متكامل يضم جميع نواحي

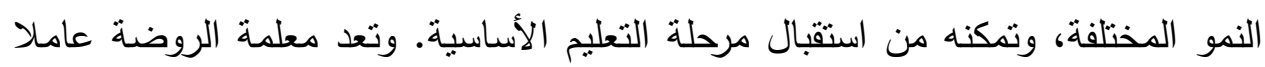
اساسيا في نجاح العملية التربوية التي تتم داخل الرياض،حيث أنها تتعامل مع مرحلة

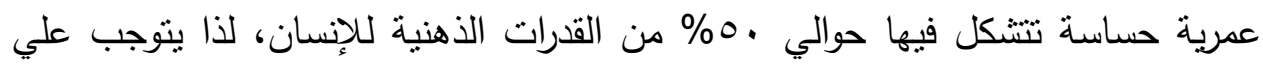
المعلمة ان تكون معدة إعدادا جيدا بحيث تكون قادرة علي تهيئة الظروف التعليمية

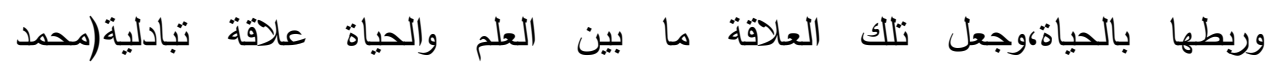

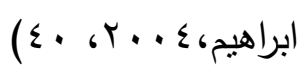

وقد أكدت العديد من الدراسات على اهية بيئة الروضة فى نمو الأطفال من

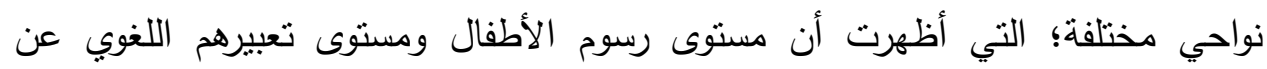
رسوماتهم، يتطور بشكل أفضل في بيئة الأركان التعليمية عنه في البيئة الصفية التقليدية، لتئية وذلك يعود إلى ما تتميز به بيئة الأركان التعليمية من تتوع في أساليب التعلم، وتتوع في لتئي المواقف والأنشطة، وهذا ما يساهم في تحقيق النمو الثامل للأطفال حسب حاجاتهم

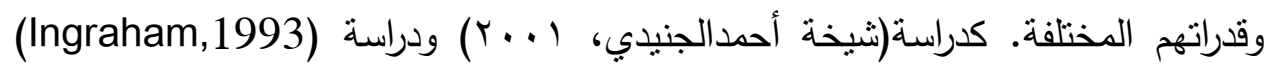

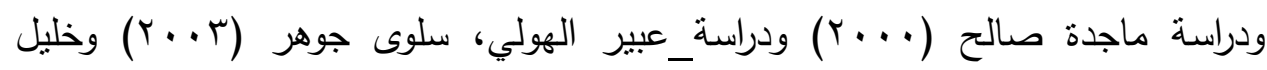

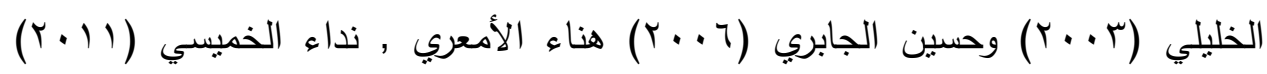

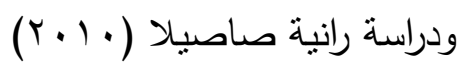

كما تقوم معلمة الروضة بعدة أدوار مهمة ورئيسة، ومن بينها دورها كداعمة لنمو

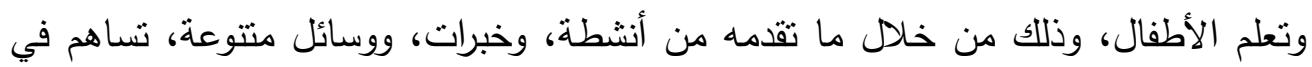
إثارة دافعية الطفل للتعلم، ومن خلال قدرتها على ملاحظة نمو الطفل والاستفادة من هذه ماهن

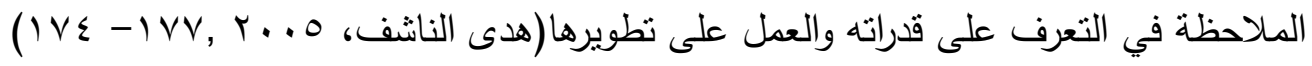




\section{مجلة " دراسات في الطقولة والتربية" - جامعة اسيوط}

ومن بين جوانب النمو في الطفل التي تسعى الروضة إلى تتميتها يحتل جانب النمو

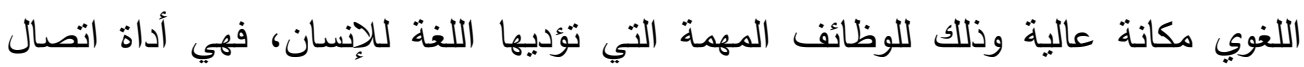

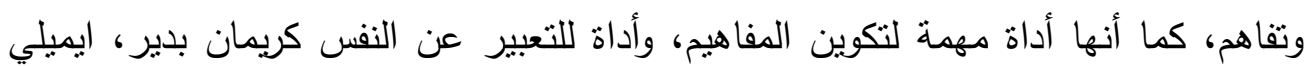

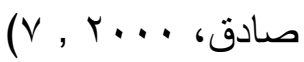

وتعد القراءة إحدى المهارات اللغوية الأساسية والتي تحقق أهدافًا بالغة الأهية للفرد،

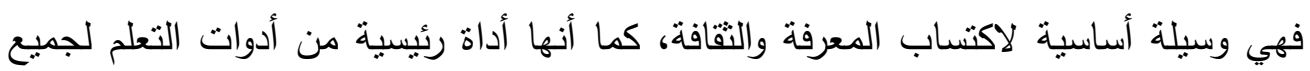

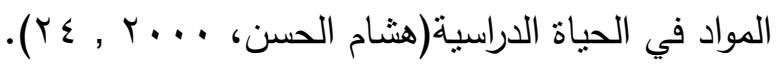

وتعتبر مرحلة رياض الأطفال مرحلة مهمة في إعداد الطفل لتعلم مهارة القراءة

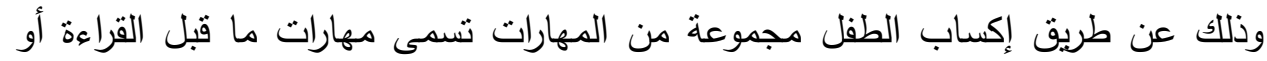

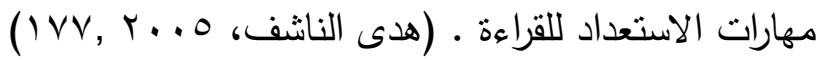

وتوصف مرحلة الاستعداد للقراءة بأنها هي الدعامة الأساسية لإكساب مهارة القراءة للطفل، كما أنها مؤشر يدل على مستوى الطفل فيما بعد من حيث تقدمه أو تأخره في

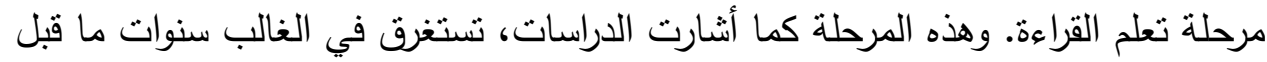
المدرسة وقد تمتن لأكثر من ذلك بسنة أو سنتين حسب قدرة الطفل، وذلك لأن القراءة

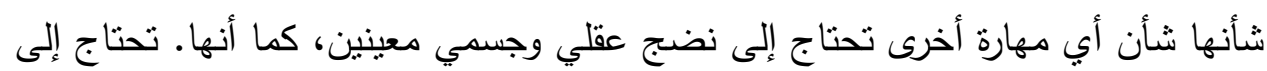

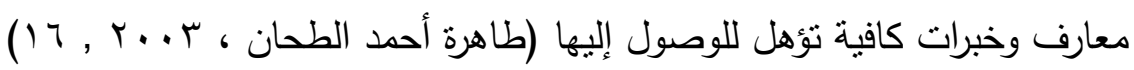

وتؤكد بعض الأبحاث على أن اكتساب الطفل لـهارات الاستعداد للقراءة في

مرحلة الروضة يمكن أن يعد مؤشرًا قويًا على قدرته المستقبلية في امتلاك مهارة القراءة،

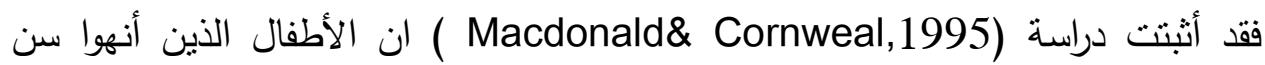
الروضة وهم يمنلكون إحدى مهارات الاستعداد للقراءة، وهي مهارة التمبيز الصوتي،

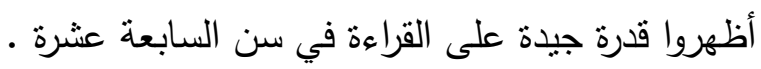

كما أن هناك مهارات أخرى لازمة لتتمية الاستعداد للقراءة مثل المهارات البصرية

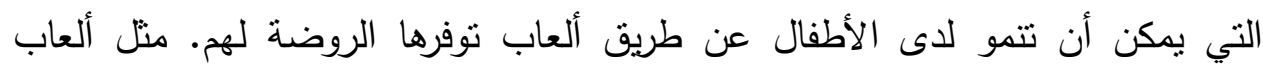

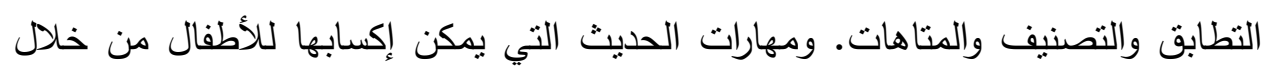


الوسائل والأنشطة المنتوعة مثل نرديد الأناشيد، والأنشطة التثثيلية، وقراءة القصص للأطفال. وصقل هذه المهارات وغيرها في مرحلة الروضة تمكن الطفل من إجادة القراءة

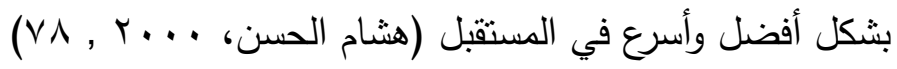

مشكلة البحث

يعتمد نجاح أي برنامج تربوي على كيفية تصميمه وتتظيمه وإدارته، فإغفال

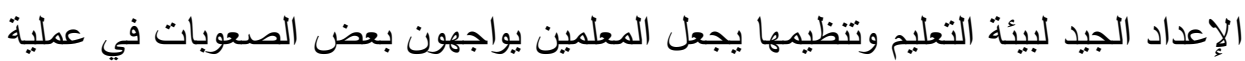
التدريس .فغالباً

يتجاهل المعلمون إعداد وتتظيم البيئة التعليمية عند التخطيط للتدريس، حيث يميل المعلمون إلى التركيز على استراتيجيات التدريس وكيفية إدارة الصف، بينما يولون أهمية قليلة للبيئة التعليمية المادية والبصرية التي تحدث من خلالها عمليتي_التعلم والتعليم .(Morrow \& McGee, 2005,.24)

وتعد مرحلة ما قبل المدرسة من المراحل المهمة في حياة الطفل، إذ تتيح له الفرصة لاكتساب العديد من الخبرات الكافية لتتمية مهاراته و استعداداته للتعلم وفيها يمكن وضع الأساس للعملية التربوية عبر مراحل التعليم المختلفة وتعد القراءة إحدى المهارات المهمة التي تساهم الروضة في إكسابها للأطفال، وتستمد أهميتها من كونها مهارة أساسية

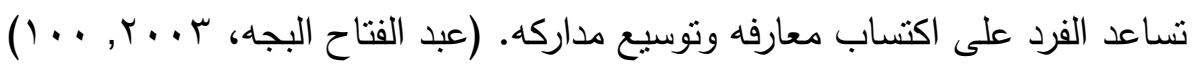
ومن خلال ما أظهرته نتائج العديد من الدراسات كدراسة زهرية ابراهيم عبد

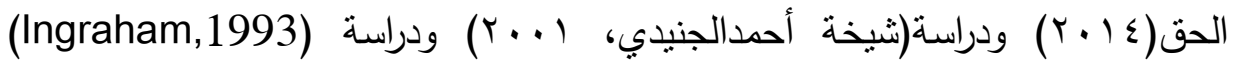

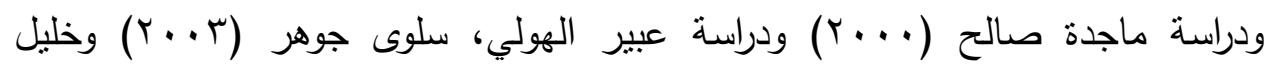

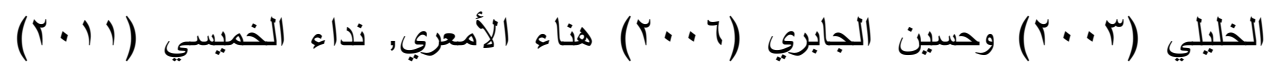

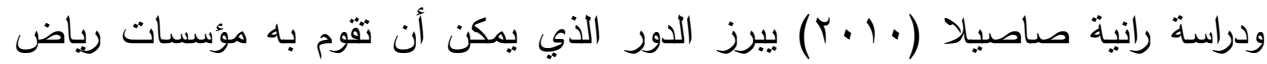
الأطفال في مساعدة الطفل على إتقان مهارة القراءة في المستقبل، وذللك عن طريق إكسابه مهارات الاستعداد للقراءة حتى يصل الطفل إلى مرحلة التعليم الأساسي وهو ممتلأك لهذه

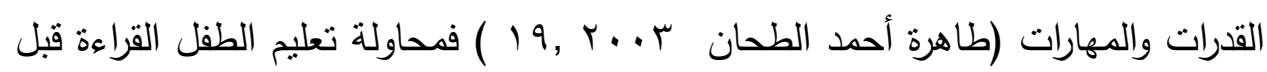




\section{مجلة " دراسات في الطقولة والتربية" - جامعة اسيوط}

أن يكون مستعدًا لها قد يؤدي إلى إطالة المدة المطلوبة للتعليم وإجهاد الطفل، كما انه قد يؤدي في بعض الأحيان إلى تكوين اتجاهات سلبية لدى الطفل نحو القراءة (هدى إلى إلهدئ

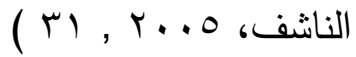

ومن أهم طرق تكوين الاستعداد للقراءة في الروضة تجهيز بيئة غنية بالأنشطة، يتفاعل معها الطفل وتمده بخبرات ومهارات منتوعة مباشرة وغير مباشره تساهم في تكوين استعداده للقراءة (نجوى بدر خضر ،

وقد أظهرت دراسة (1991 Morrow \& Rand) أن التصميم الجيد للبيئة الصفية وإثراءها بالوسائل والأدوات المناسبة يدعم بشكل كبير لعب الأطفال الممهد للقراءة

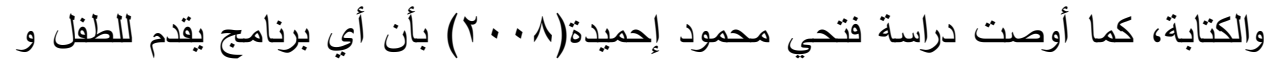
يهدف إلى تتمية استعداده للقراءة يجب أن يكون قائمًا على الوسائل والأنشطة المترابطة بهانة

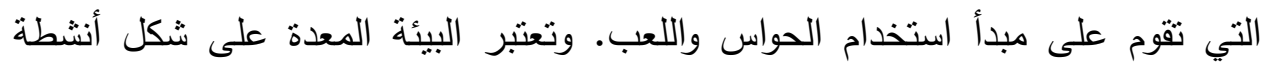

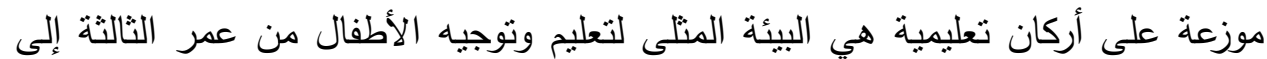
السادسة

كما تؤدي المعلمة دورًا هامًا في تخطيط وتتفيذ الأنشطة التي تؤدي إلى تتمية جميع مهارات الأطفال في الروضة بحيث يكون هذا التخطيط بنا على قدرات أطفالها

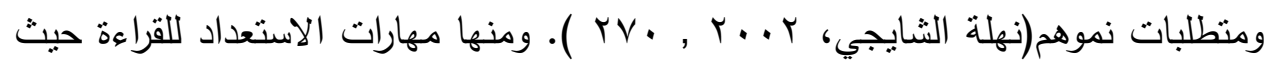
تعد المعلمة الأنشطة التي تساهم من خلالها في إكساب الأطفال تلك المهارات(عبد الفتاح

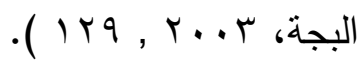

وذلك ما تؤيده دراسة (2001 , Teisl,James et al) التي اوضحت ان معلمات الروضة يمكنه إلى حد كبير تحديد الصعوبات التي قد يواجهها الأطفال مستقبلا في القراءة من خلال ملاحظتهم الدقيقة لأطفالهم، وبالتالي يمكنهم تقديم الأنشطة للأطفال

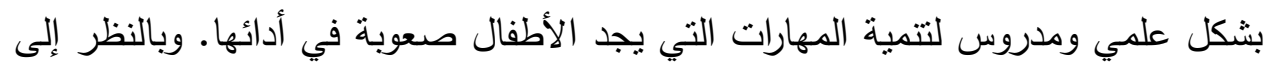

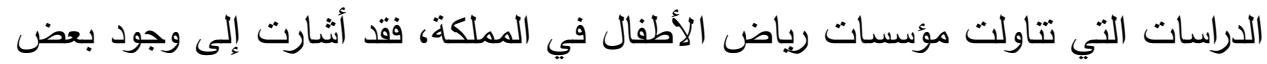
أوجه النقص التي قد تحد من تحقيق الأهداف التربوية لهذه المؤسسات، وهذا يتفق مع ما لالتهات 
أظهرته دراسة العميل التي أوضحت نتائجها أن مؤسسات رياض الأطفال تعاني من (Am-) (Ameel,2002 قلة المعلمات المؤهلات ذوات الخبرة في التعامل مع الأطفال.

وبالنظر إلى طريقة تعليم القراءة للأطفال من خلال منهج الجديد المطبق في مؤسسات رياض الأطفال في جمهورية مصر العربية، فقد أكد القائمون على إعداد هذا

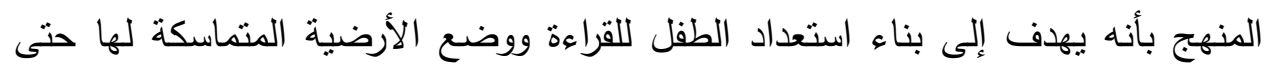
يتمكن الطفل من الوصول إلى القراءة براحة ويسر حسب قدراته الخاصة به ونظرًا لأهمية إكساب الطفل مهارات الاستعداد للقراءة خلال مرحلة رياض الأطفال وذللك كما بينت

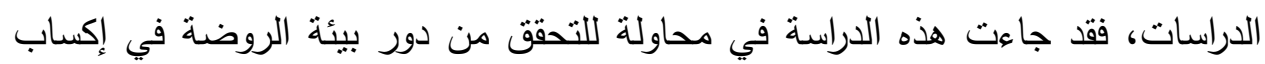
الأطفال بعض مهارات الاستعداد للقراءة.

واستتادًا إلى ما أثنارت إليه نتائج وتوصيات الدراسات السابقة ونتائج الزيارات

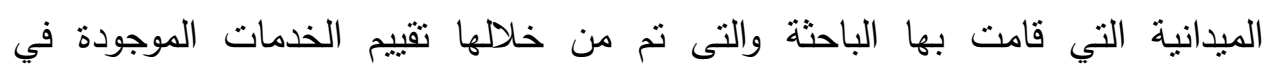
الروضات، تبين وجود اختلاف في الخدمات المقدمة مما يؤدي إلى تباين الاهنمام بجوانب

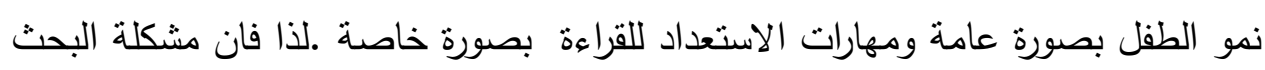

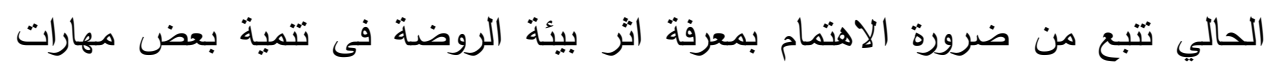
الاستعداد للقراءة لاى اطفال الروضة ضروة الأيمان وللتصدي لمشكلة البحث حاولت الباحثة الإجابة عن الأسئلة التالية: - - ما مدى توافر الوسائل والتجهيزات الصفية في تتمية بعض مهارات الاستعداد

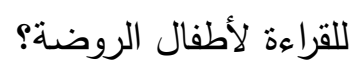
- ما مدى نوافر الانشطة الصفية المستخدمة من قبل المعلمة لتتمية مهارات الاستعداد للقراءة لأطفال الروضة؟ - - ما مدى العلاقة بين بيئة الروضة ومهارات الاستعداد للقراءة لدي اطفال الروضة؟ 


\section{مجلة " دراسات في الطفولة والتربية" - جامعة اسيوط}

\section{مصطلحات البحث}

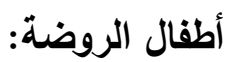

- تعرف الباحثة أطفال الروضة اجرائيا : هم الأطفال الملتحقون برياض الأطفال

$$
\begin{aligned}
& \text { الحكومية، ممن تتروح اعمارهم بين ع-7 سنوات. } \\
& \text { بيئة الروضة : }
\end{aligned}
$$

- عرفت ثثاء الضبع بيئة الروضة على أنها "مجموع العناصر التي يتألف منها الموقف

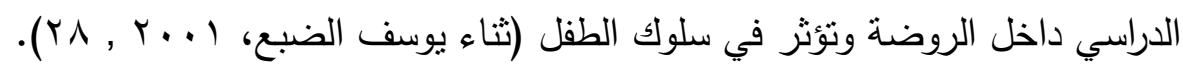
- ويقصد بييئة الروضة في هذا البحث " مجموع العناصر الموجودة داخل غرفة الصف في الروضة والتي يتفاعل الطفل معها وتساهم في إكسابه مهارات الاستعداد للقراءة، وتتثمل العناصر المادية والمتمثلة في التجهيزات الصفية والوسائل، والعناصر غير المادية والمتمنلة في معلمة الروضة من حيث الأنشطة التي تقدها للأطفال".

مهارة:

- - ويقصد بالمهارة في هذه البحث: " قدرة الطفل على القيام بأحد الأعمال اللازمة لإتمام عملية القراءة بسهولة ونجاح". - الاستعداد للقراءة: - إن

- - يعرف الاستعداد للقراءة أيضًا بأنه "نمو مهارات اللغة المبكرة، والتمبيز السمعي والبصري، والقدرات المعرفية، والتآزر الحركي الدقيق والتي تعتبر متطلبات سابقة

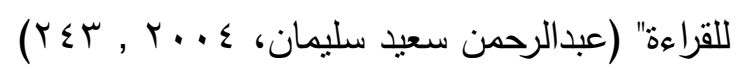

- - وتعرف الباحثة مهارات الاستعداد للقراءة ببعض المهارات البصرية وتتثل مهارة التعرف أثنكال بعض الحروف المنفصلة والمتصلة، مهارة التمييز البصري بين المثيرات البصرية المختلفة كالأشكال والأحجام، مهارة التمييز البصري بين أثنكال 
الحروف والكلمات، وبعض المهارات السمعية وتشم لمهارة التمييز السمعي بين أصوات الحروف، مهارة التمييز السمعي بين أصوات الكلمات من حيث بدايتها ونهايتها الصوتية، مهارة التمييز السمعي بين الكلمات المسجوعة وبعض مهارات التحدث وتشمل تتمية حصيلة الطفل من المفردات اللغوية، مهارة الحديث بجمل سليمة.

اهداف البحث

يسعى هذا البحث إلى تحقيق الهذف الرئيس التالي:

التعرف على علاقة بيئة الروضة في تتمية بعض مهارات الاستعداد للقراءة لدى الأطفال. ويتفرع من الهدف الرئيس الأهداف الفرعية التالية:

1 - التعرف على مدى ثوافر الأنشطة الصفية التي تستخدمها المعلمة لتتمية بعض مهارات الاستعداد للقراءة لدى الأطفال.

ץ- التعرف على ما مدى ثوافر الوسائل والتجهيزات لتمية بعض مهارات الاستعداد للقراءة لدى الأطفال

ץ- التعرف على مدى توافر مهارات الاستعداد للقراءة لدى أطفال الروضة ؟

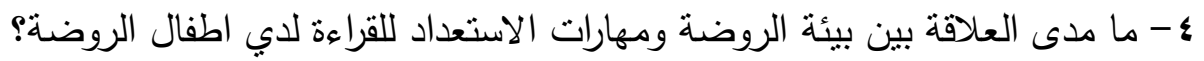

\section{الهمية البحث}

- أهمية المراحل النمائية التي يكتسب فيها الطفل كثيراً من المهارات - تتمثل أهمية هذا البحث في معرفة مدى توافر الأنشطة الصفية التي تستخدمها المعلمة لتتمية بعض مهارات الاستعداد للقراءة لدى الأطفال. - تتمنل أهية هذا البحث في معرفة مدى توافر الوسائل والتجهيزات لتتمية بعض مهارات الاستعداد للقراءة لدى الأطفال - قد يستقيد من هذا البحث مصممو برامج إعداد وتدريب معلمات رياض الأطفال - - الاهتمام بمرحلة الطفولة يعد استتمارًا أمنل لبناء مستقبل أي أمة 


\section{مجلة " دراسات في الطقولة والتربية" - جامعة اسيوط}

- أن هذه البحث يتتاول موضوعًا هامَا وهو تتمية مهارات الاستعداد للقراءة لدى طفل

الروضة

- قد بساعد البحث القائمين على رياض الأطفال في تفعيل دور بيئة الروضة في إكساب الأطفال بعض المهارات المناسبة لهم.

حدود البحث

- - الحدود المكانية: نم تطبيق هذه الدراسة على عينة من الروضات الحكومية بمحافظة اسيوط وعددهم عشر روضات تابعة لوزارة التربية والتعليم

- الحدود البشرية: اقتصرت هذه الدراسة على معلمات رياض الأطفال في الروضات الحكومية , الأطفال في المرحلة العمرية من ( 0) إلى ( ب) سنوات.

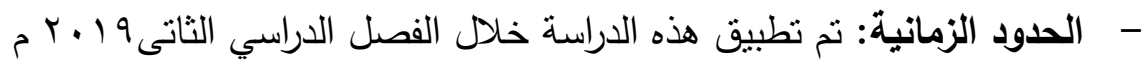
- - الحدود الموضوعية: اقتصر هذا البحث على بيئة الروضة( المعلمة- الوسائل)

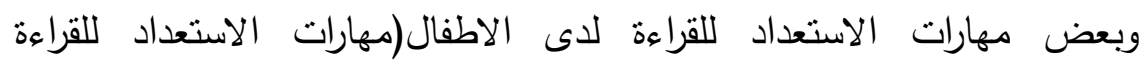

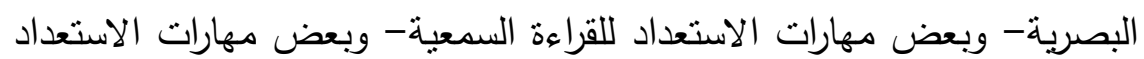

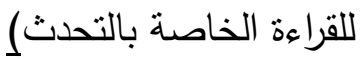

\section{اهمية البحث}

- - أن الاهتمام بمرحلة الطفولة يعد استثمارًا أمثل لبناء مستقبل أي أمة - أن مرحلة الطفولة من المراحل المهمة في حياة الإنسان، ففيها تتشكل أساسيات شخصيته، وتتحدد بشكل كبير ملامح نموه المستقبلية من جميع النواحي. - أن هذه الدراسة تتتاول موضوعًا هامًا وهو موضوع إكساب الأطفال مهارات الاستعداد للقراءة، حيث تعد القراءة من أهم وسائل التعليم والتتقيف للإنسان، كما ينم عن طريقها نقل المعرفة والتراث الإنساني التقافي من جيل إلى جيل عبر قراءة الإنسان للمادة المكتوبة 
- ما يمكن أن تخرج به هذه الدراسة من نتائج وتوصيات قد تساعد القائمين على رياض الأطفال في تفعيل دور بيئة الروضة في إكساب الأطفال بعض مهارات الاستعداد للقراءة، وإعطاء أهية اكبر لهذه المهارات.

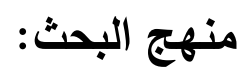

انطلاقًا من أهداف البحث والبيانات المراد الحصول عليها لتحديد علاقة بيئة الروضة ببعض مهارات الاستعداد للقراءة لدى طفل الروضة فقد نم تطبيق المنهج الوصفي التحليلي الذي " يعتمد على دراسة الظاهرة كما توجد في الواقع، ويهتم بوصفها لتهاه

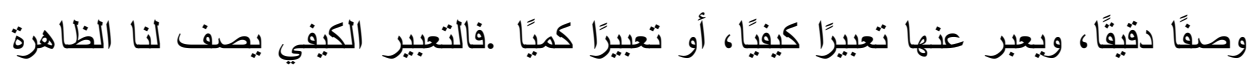

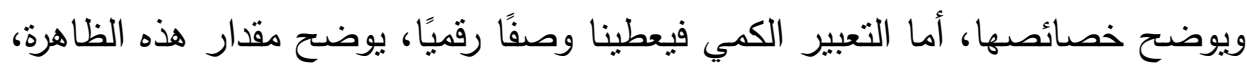

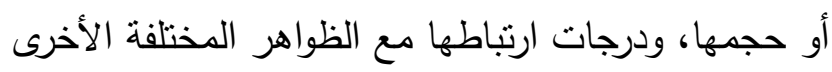

\section{اجراءات البحث}

عينة البحث

عينة الروضات : فقد تم اختيار عينة الروضات بالطريقة العشوائية وبلغ عدد الروضات التي شملتها العينة (• (1) روضات من الروضات الحكومية التابعة لوزارة التربية

$$
\text { والتعليم في مدينة أسيوط . }
$$

عينة المعلمات: شمل البحث المعلمات من مجتمع البحث وقد بلغ عدد المعلمات ( • ) معلمة

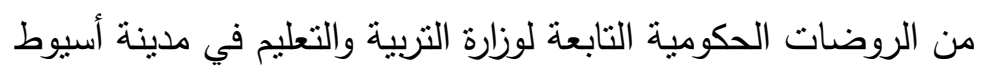

عينة الاطفال: وقد بلغ عددهم (.0 ) طفلا وطفلة

الاطار النظري

بيئة الروضة

للبيئة أثنر كبير في حياة الطفل، فمن البيئة يتعلم ويتعود نمط الحياة الاجتماعية

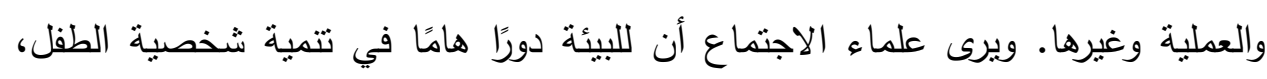




\section{مجلة " دراسات في الطقولة والتربية" - جامعة اسيوط}

وعلماء التربية وعلم النفس يرون أن البيئة تلعب دورًا كبيرًا في تتمية مدارك الطفل، وبناء علاقاته مع الغير ومع ما يحيط به، وهي التي تكون سبيًا في استخدامه لحواسه الخمس، لئه

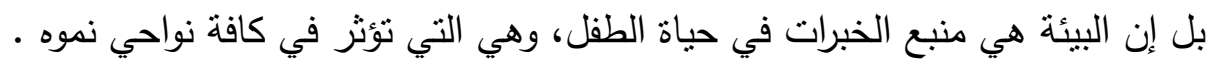
كما أن للبيئة أثرًا في التعليم المدرسي، فعند وصول الطفل إلى الصف الأول الابتدائي يكون قد مر في مرحلة سار فيها تطوره بأسرع ما يمكن أن يكون خلال حياته وله

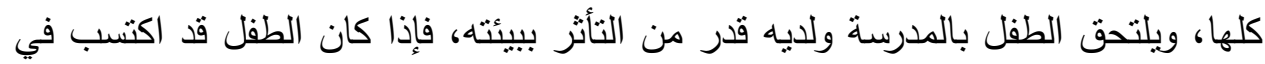

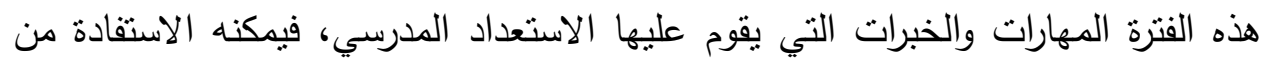

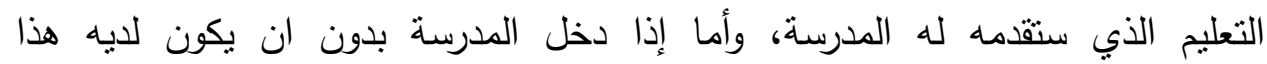
الاستعداد، سيصعب عليه كثيرًا الاستفادة الكاملة من الخبرات التي تقمها المدرسة وقد

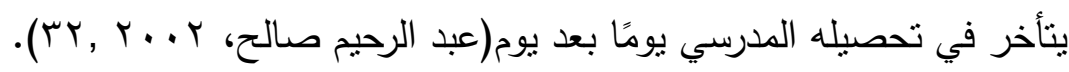

لذللك فإن المهتمين بتربية الطفل دائما يبحثون عن برامج ناجحة يقدمونها للطفل

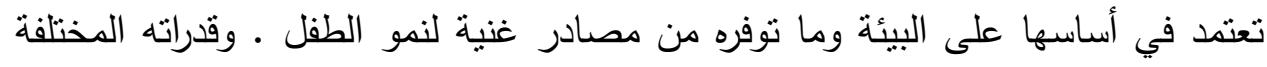

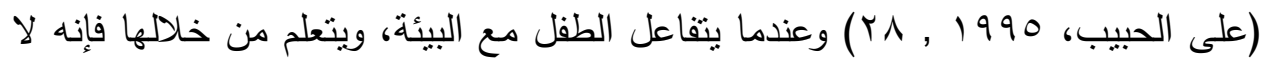

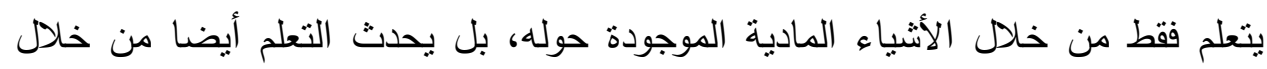

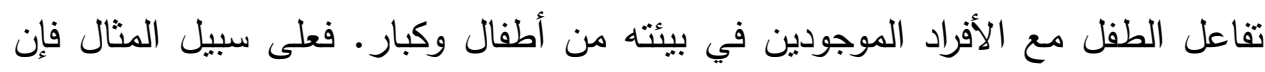

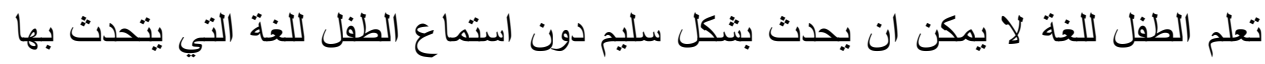

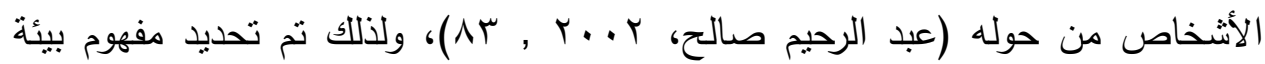
الروضة في هذه الدراسة بالعناصر المادية والمتمنلة في الوسائل والتجهيزات الصفية داخل غرفة الصف، والعناصر غير المادية والمتمنلة في معلمة الروضة.

\section{معلمة الروضة}

يعتمد نجاح مؤسسات رياض الأطفال في تحقيق أهدافها على مدى وجود معلمات مؤهلات نأهيلا نربويًا متخصصًا للعمل مع الأطفال في هذه المرحلة الحساسة من حياتهم. فنجاح المعلمة في عملها يعد نجاحًا للروضة في تحقيق أهدافها, وذلك لما تقوم به المعلمة من دور واضح في تهيئة المجال للطفل لاكتساب خبرات تزيد من قدرته على لهـ 
توجيه مسار حياته، سواء كان ذلك من خلال تناعلها مع الأطفال، أو من خلال تتظيمها

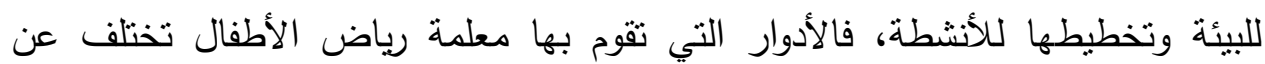

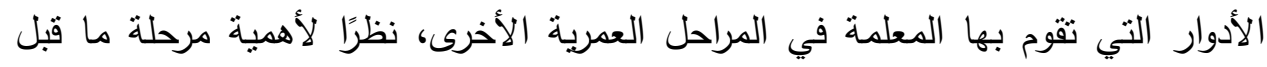

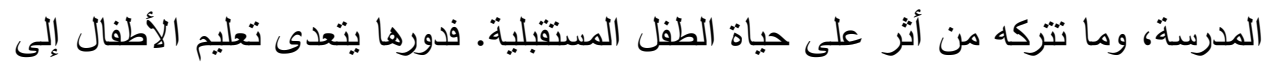

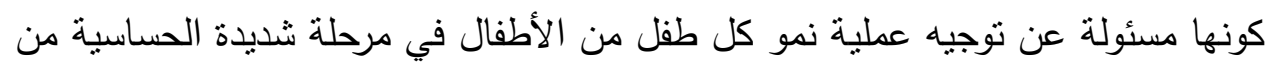

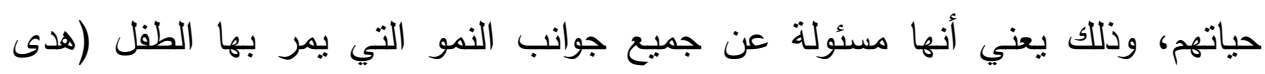

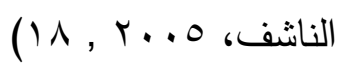

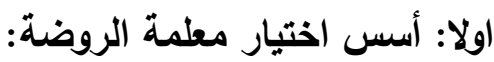

إن توفير المعلمات القادرات على تعليم الأطفال وتربيتهم ينظلب اختيار العناصر

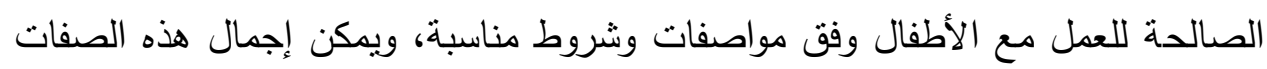

$$
\text { أ- الجانب البي: }
$$

إن الصحة الجسمية للمعلمة وخلوها من العاهات والإعاقات الجسدية تعد شرطًا

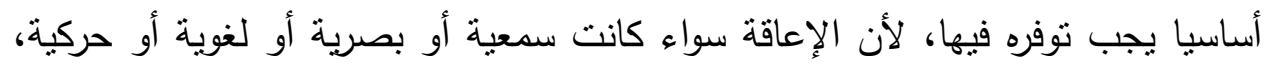
من شأنها أن تعوق المعلمة عن القيام بمهيتها في تتمية حواس الطفل ومهاراته الجسمية.

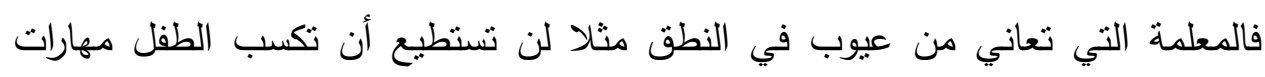

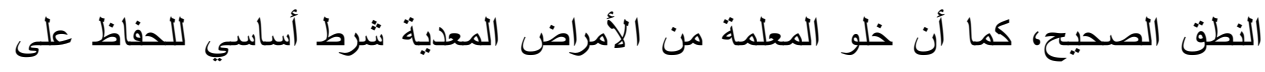

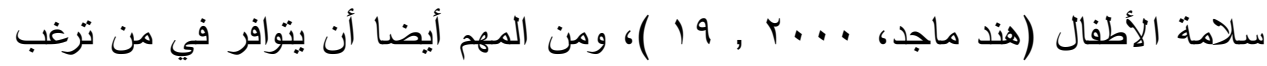

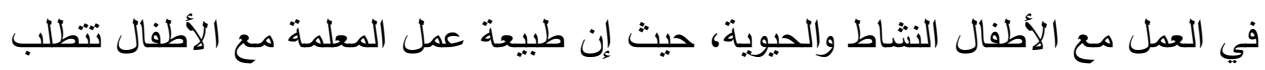

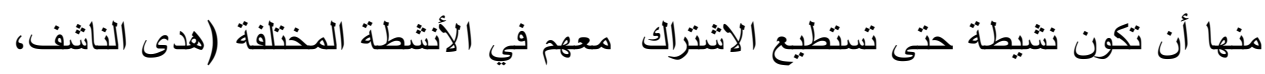

$$
\begin{aligned}
& \text { (IVA, r... } \\
& \text { ب-الجانب العقلي: }
\end{aligned}
$$

إن العمل مع الأطفال يتطلب أن تكون المعلمة على قدر مناسب من الذكاء

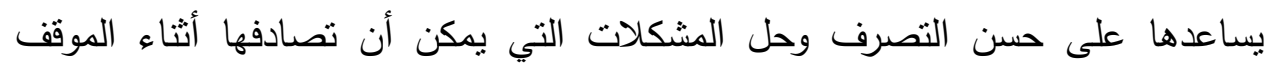




\section{مجلة " دراسات في الطقولة والتربية" - جامعة اسيوط}

التعليمي، كما يمكّنها ذلك من استيعاب المفاهيم النظرية الأساسية المتعلقة بنمو وتعليم الأطفال، وتطبيقها في الواقع بشكل عملي بما بحقق استفادة الأطفال، كما أن ذكاء

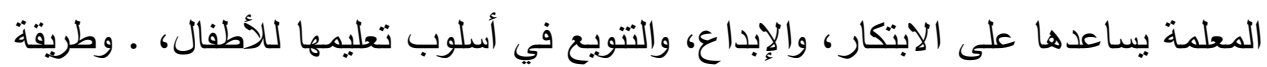

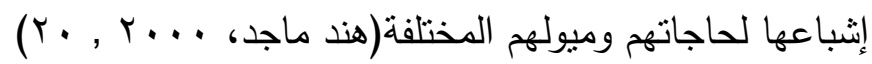

ج- الجانب النفسي والاجتماعي:

يشترط في معلمة رياض الأطفال أن تكون محبة للأطفال ومتقبله لهم، إذ أن تقبلها

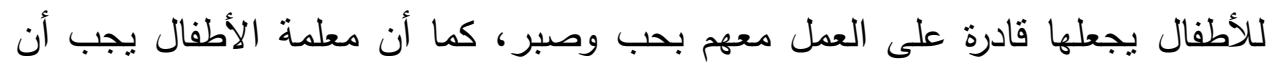
تتمتع بدرجة عالية من الاتزان الانفعالي وضبط النفس حتى تتعامل مع المشكلات التي

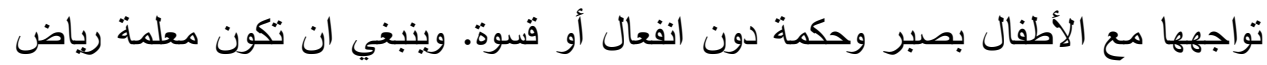

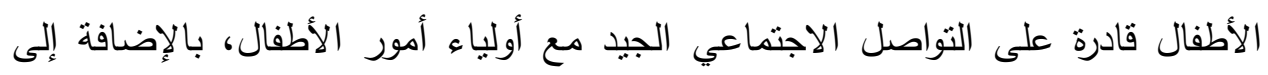

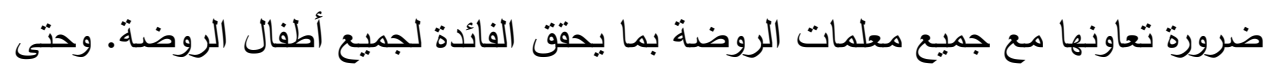

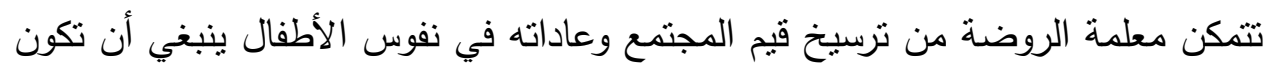

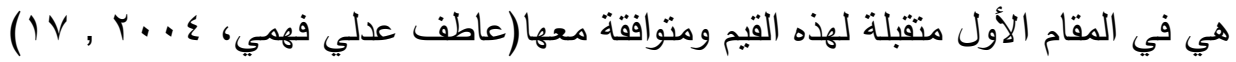

ثانيًا: إعداد معلمة الروضة:

أ- الإعداد قبل العمل: من الضروري أن يتم تأهيل معلمة الروضة تأهيلا تربويًا من خلال

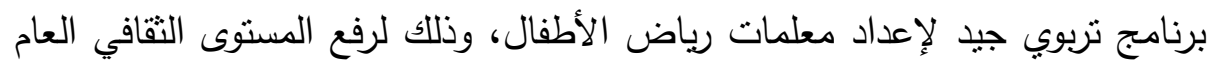
لها وتزويدها بخلفية مناسبة عن خصائص المرحلة العمرية للطفولة المبكرة واحتباجاتها، بالإضافة إلى إكسابها المهارات المتعلقة بتعليم الأطفال وتخطيط

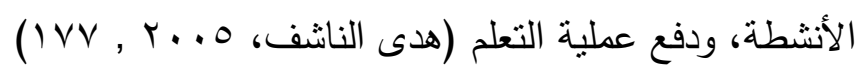

ب- النمو المهني أثناء العمل: بالإضافة إلى إعداد معلمة الروضة قبل عملها في رياض الماض

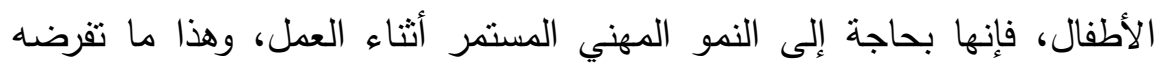
طبيعة العصر من انفجار معرفي أدى إلى تطور مستمر في جميع مجالات

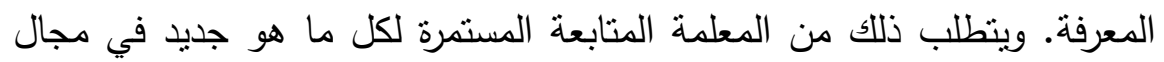


الفكر والممارسة في رياض الأطفال، وحضور الدورات والندوات المتعلقة بمجال

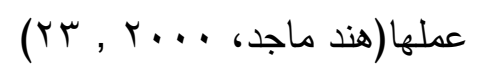

ثالثا : المهام المهنية لمطلمة الروضة تقوم معلمة الروضة بأدوار عديدة ومنداخلة وتؤدي مهامًا كثيرة، لعل من أبرزها ما يلي: 1. دور المعلمة كمساعدة لعملية النمو الثامل للطفل:

ينمو الطفل من خلال تفاعل معطياته وقدراته واستعداداته الخاصة مع البيئة بكل

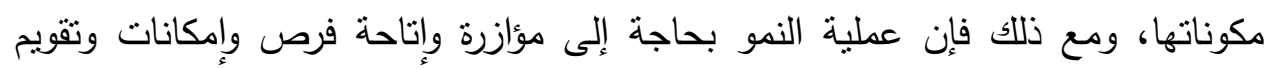

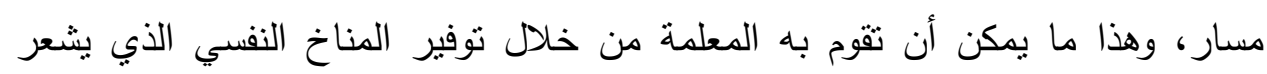
الأطفال بالأمان والاستقرار العاطفي، والعمل على إنبان إنباع حاجاتهم الجسمية والعقلية

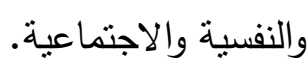

كما تلعب المعلمة دورًا هامًا في التعامل مع المشكلات السلوكية للأطفال، ويبدأ

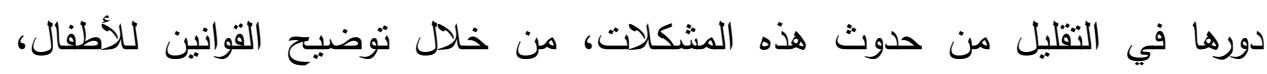

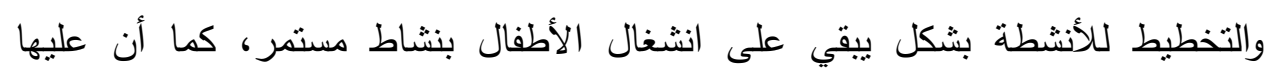

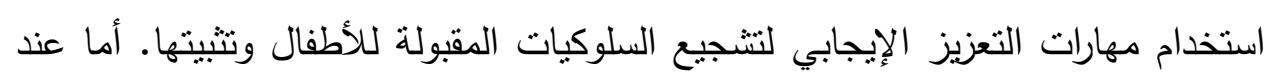

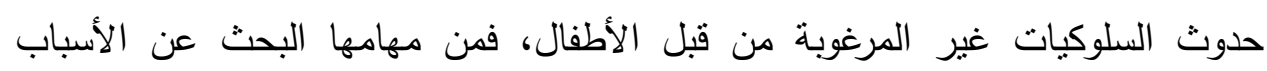

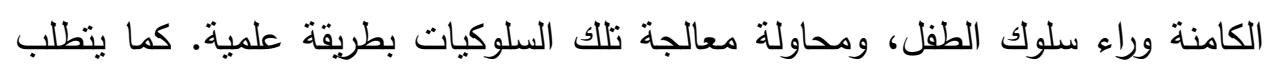

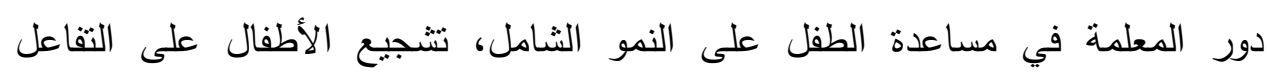

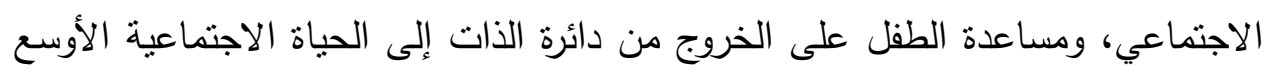

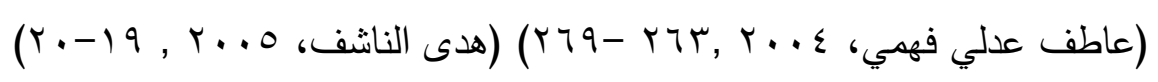

r. دور المعلمة في تخطيط و إعداد الأنثطة التعليمية :

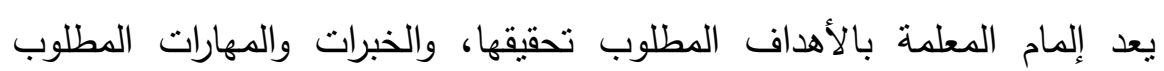

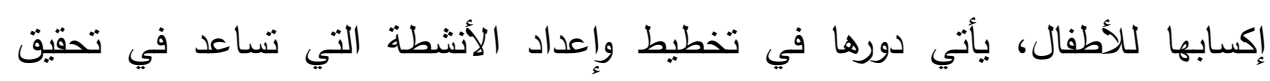
الأهداف، وذلك يتطلب منها عدة مهام منها تحديد الوسائل التعليمية المناسبة للنشاط، 


\section{مجلة " دراسات في الطقولة والتربية" - جامعة اسيوط}

واختيار أساليب العرض المناسبة لهذه الوسائل، واختيار المكان الذي سيقام فيه النشاط.

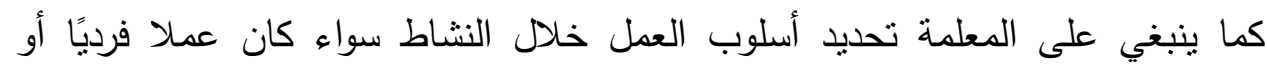
جماعيًا، وتحديد أساليب نوجيه الأطفال والتفاعل معهم وملاحظة سلوكهم أثناء النشاط

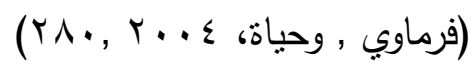
r. بور المعلمة في تقويم الأطفال : يساعد نقويم الأطفال معلمة الروضة في التعرف على مستوى قدرات الطفل من

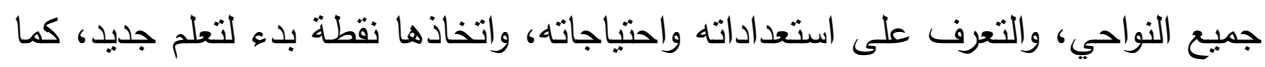
يساعد التقويم المعلمة على التعرف على الفروق الفردية بين الأطفال حتى تتمكن من

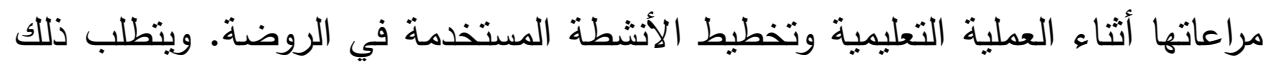

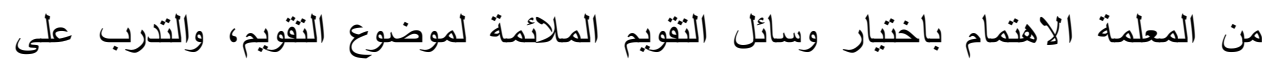

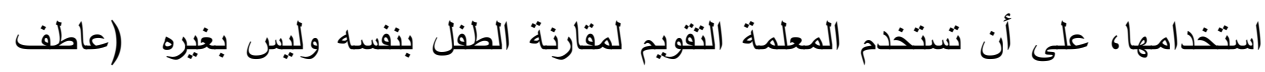

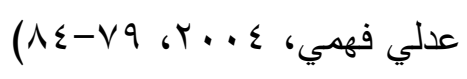

ع. دور المعلمة كممثلة للمجتمع:

يتطلب هذا الدور من المعلمة أن تسعى إلى تعزيز القيم والمفاهيم السائدة في

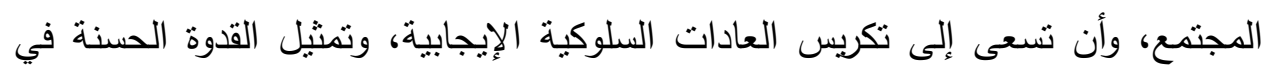
المظهر والسلوك لينشأ الطفل محبًا لمجتمعه منمثلا لقيمه. ولكي تتمكن المعلمة من القيام بهذا الدور لا بد أن تكون قادرة على التواصل الاجتماعي مع أسرة الطفل حيث إن التنشئة الاجتماعية تبدأ من البيت، ومن المهم أن يتحقق التوافق والتكامل بين أساليب التتشئة

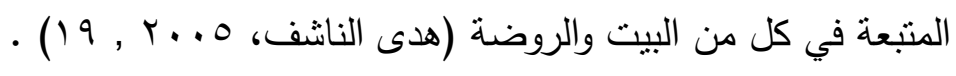

الوسائل والتجهيزات الصفية

يؤدي اللعب دورًا هاما في العملية التربوية في رياض الأطفال، وذللك لما للعب من فوائد عديدة منها تتمية قدرة الطفل على التفكير وتزويده بمهارات وخبرات ومعلومات جديدة. كما يساهم اللعب في تطوير سلوك الطفل الاجتماعي، بالإضافة إلى تحقيق الاتزان الانفعالي للطفل من خلال إزالة توتره وإنشباع رغباته وتصريف طاقاته (نهلة 


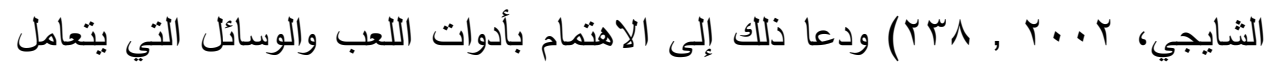
معها الطفل أثناء لعبه في الروضة، واعتبارها عنصرا هاما في تربية الطفل ومجالا خصبا لإكسابه مفاهيم وخبرات ومهارات لا يمكن أن يكتسبها بطرق أخرى ـ ومما يؤكد

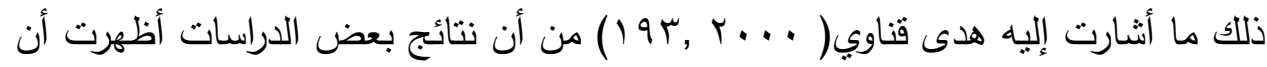

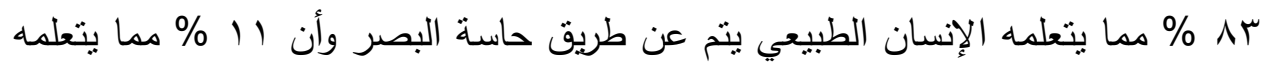

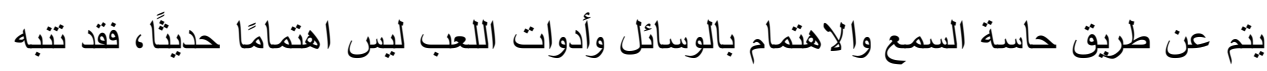

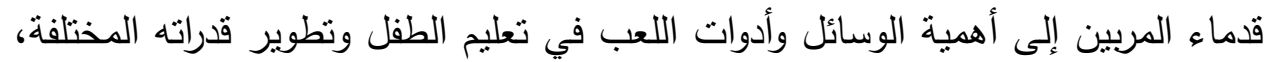
ومنهم المربي "جان كومينوس" الذي ألف كتابه الثهير (عالم الصور (Orbis picture) الذي كان أول كتاب مصور موجه للأطفال يهدف إلى تعليمهر باستخدام حاسة البصر.

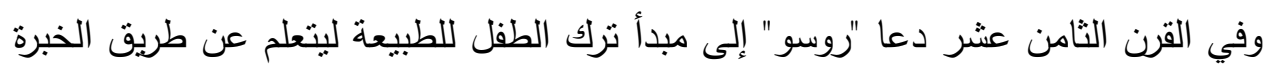

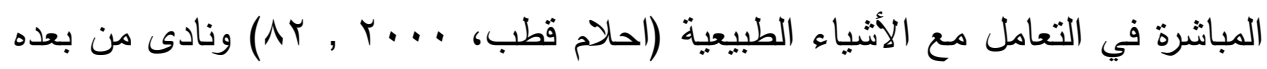

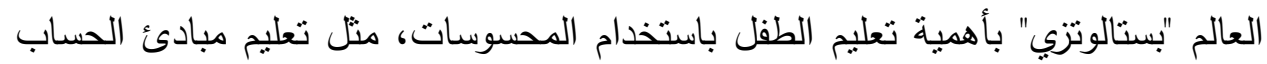

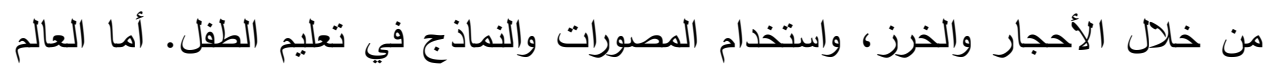
"فروبل" فقد ابتكر عددًا من الوسائل أطلق عليها اسم (الهدايا)، وهي تهدف إلى فئى تتمية

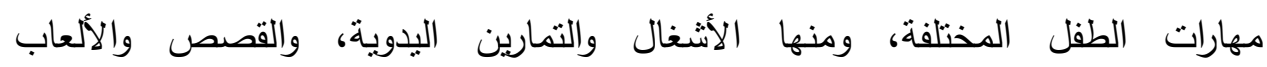

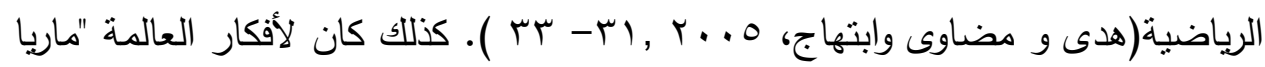
منتسوري" أهمية كبيرة في إبراز دور الوسائل في تحليم الطفل، فقد ابتكرت مجموعة من

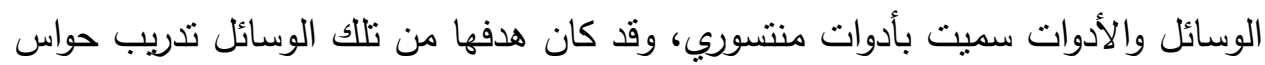

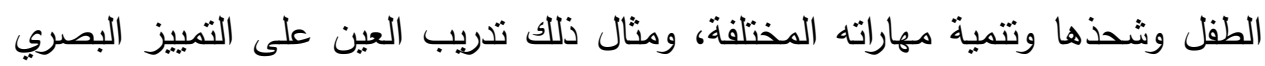

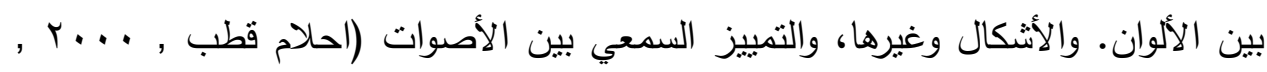

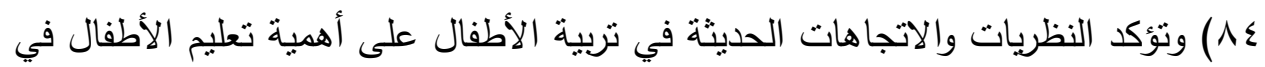

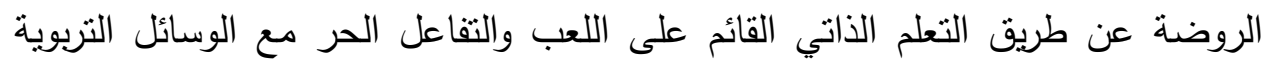

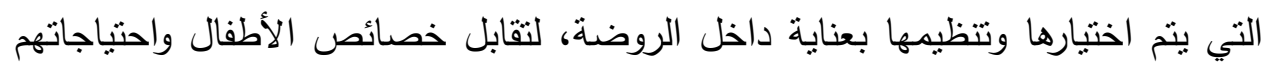

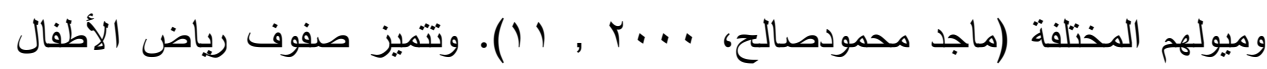
باختلافها من حيث الثكل والتقسيم الداخلي عن أي فصل دراسي وذللك نظرًا لطبيعة 


\section{مجلة " دراسات في الطقولة والتربية" - جامعة اسيوط}

العمل التربوي بها، حيث تقسم إلى أركان تعليمية يتوزع فيها الأطفال حسب اختيارهم

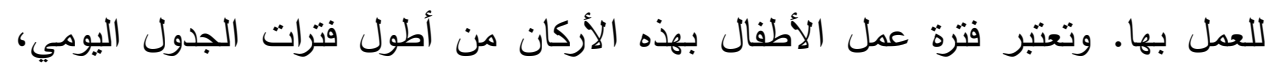
ويجب أن تحدد الأهداف التربوية التي يحققها كل ركن، وأن تشتمل هذه الأركان على على الأنى الأدوات والوسائل التي يحتاجها الأطفال لممارسة أنشطة كل ركن مع مراعاة التجديد

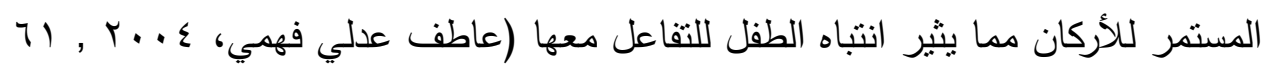
(or-

\section{انواع الوسائل والتجهيزات الموجودة في غرفة الصف بالروضة}

فيما يلي عرض لأهم الوسائل والتجهيزات الصفية في فصل الروضة وتوزيعها داخل الفصل:

\section{1 - وسائل وتجهيزات خاصة باللعب الإيهامي:}

في هذا الركن يقوم الأطفال بتمثيل الأدوار الاجتماعية المختلفة، ويحقق هذا الركن

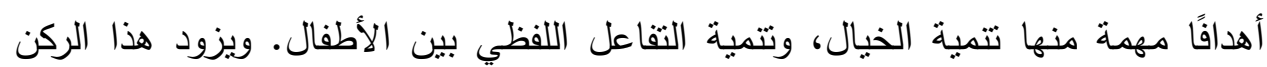

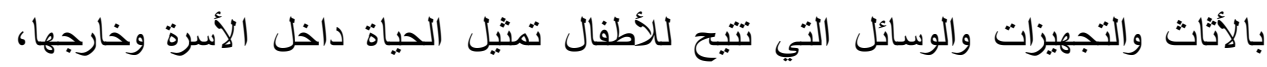
ويؤثث الركن بأثناث مناسب لحجم الأطفال كالأثاث الذي يمثل المطبخ، أو غرفة الجلوس. وغالبية أدوات وتجهيزات هذا الركن يمكن تجميعها دون الحاجة إلى شرائها، ومن أمثلتها:

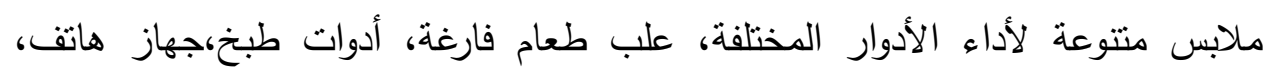

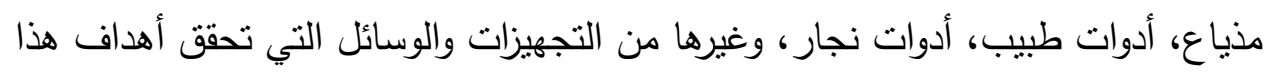

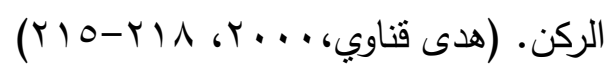

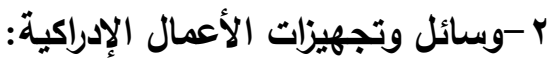

من أهم وسائل هذا الركن أدوات التصنيف والتي يصنف من خلالها الطفل الأشياء حسب خاصية معينة مثل الحجم أو اللون، وأدوات التطابق ومن خلالها يقوم الطفل بمطابقة شيئين متساوبين في خاصية معينة كالثكل أو الحجم أو اللون، وأدوات التسلسل ومن فينه منل تسلسل الأحجام والأطوال والألوان، والأحاجي وهي الألعاب التي يقوم الطفل من

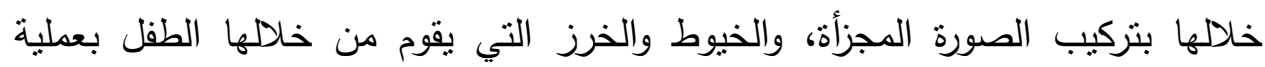


اللضم، وأدوات الطرق وغيرها. ومن الأهداف التي يحققها هذا الركن تتمية العضلات

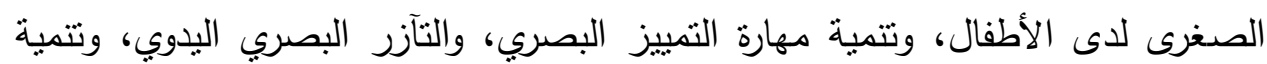
مهارات حل المشكلات

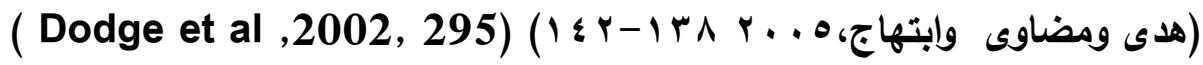
r- وسائل وتجهيزات البناء أو المكعبات: إن النشاط الأساسي الذي يقوم به الطفل في هذا الركن هو البناء الحر بالمكعبات،

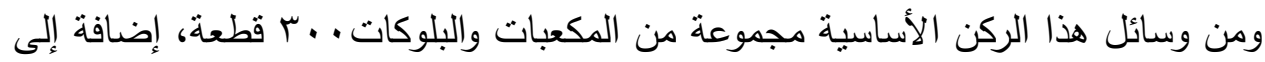
بعض الأدوات - الخشبية يتراوح عددها ما بين •ـهالأخرى المكملة لبناء الطفل والمثيرة لخياله، منل السيارات والحيوانات وغيرها. ويحقق هذا الركن عدة أهداف منها تتمية قدرة الطفل على التمييز البصري وتتمية قدرته على التطابق، والتسلسل، والتوافق العضلي،

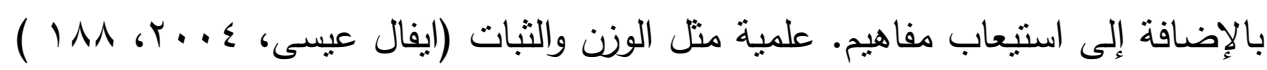

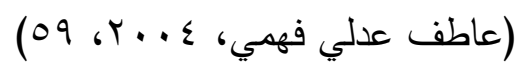
ـ - وسائل وتجهيزات المطالعة والقراءة :

في هذا الركن يقوم الأطفال بتصفح الكتب ومطالعتها، والاستماع إلى قصة مسجلة

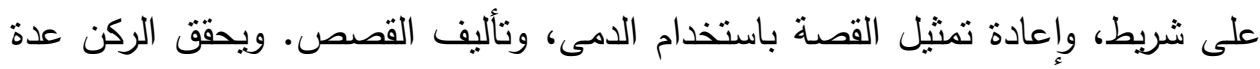

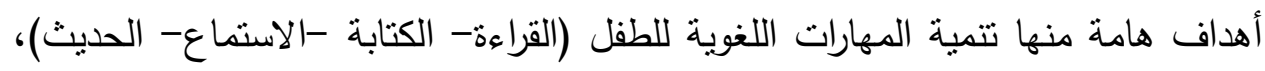

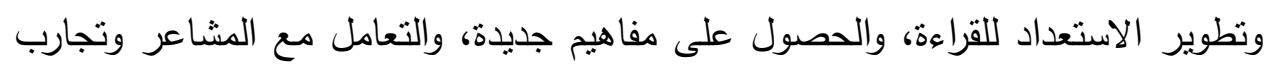

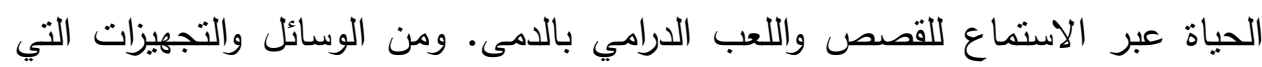

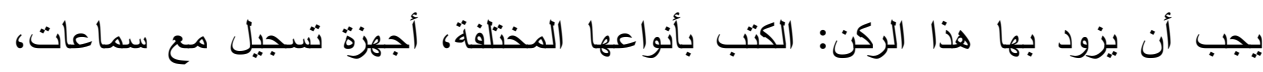

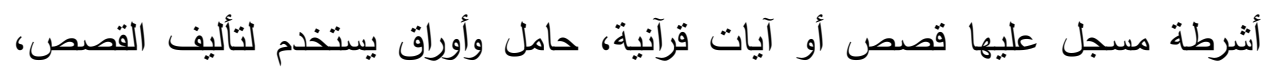

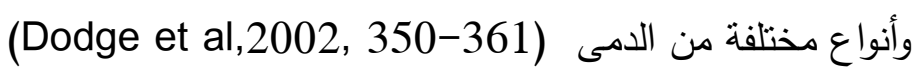
ه- - وسائل وتجهيزات التعبير الفني: 


\section{مجلة " دراسات في الطقولة والتربية" - جامعة اسيوط}

يهرف هذا الركن إلى تحقيق عدة أهداف مهمة منها مساعدة الطفل على التعبير

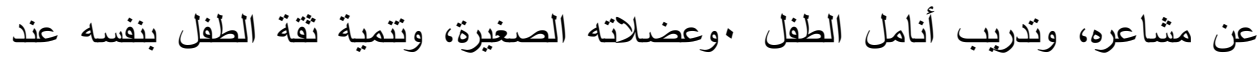
إنجاز عمله الفني، واكتشاف الألوان المختلفة. ويتطلب إعداد الركن توفير مواد وخامات يمكن أن يستخدمها الطفل في التعبير الفني، وهي كثيرة ومنتوعة ومن الصعب حصرها،

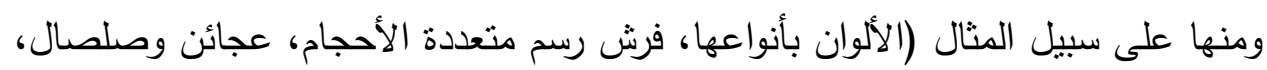

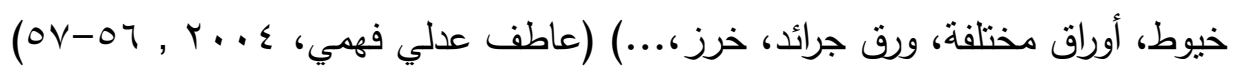
צ- وسائل وتجهيزات البحث والاكتثاف:

يهدف هذا الركن إلى تحقيق عدة أهداف للأطفال أهمها التعرف على جوانب الحياة وما بها من أثنياء طبيعية من كائنات حية وجمادات، وتتمية مهارات التفكير العلمي، وتكوين ثروة من المعلومات والمعارف لدى الطفل، وتلبية حاجته للاسنطلاع.

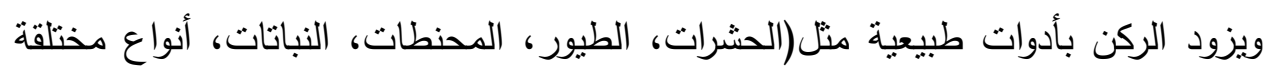

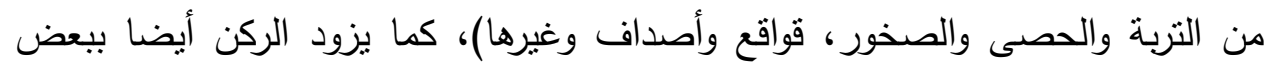

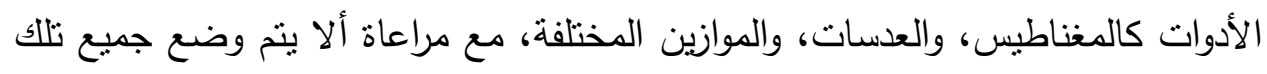
الأدوات في الركن دفعة واحدة، بل نتغير وتتبدل مع تغير الخبرات المراد إكسابها للأطفال

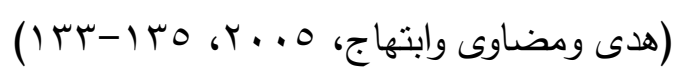

ويمكن أن تتوفر وسائل أخرى في غرفة الصف، نظرًا لإمكانية إضافة أركان جديدة من فترة إلى أخرى، منل ركن اللعب بالرمل والماء، وركن النجارة، وتتتم إضافة تلك الأركان

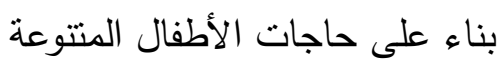

لكي تحقق الوسائل المستخدمة في رياض الأطفال أهدافها التربوية، يجب أن تتوفر فيها بعض الثروط، ومن أهمها: - - أن تكون منتوعة بحيث تقابل احتباجات الأطفال المختلفة. - أن نراعي أعمار الأطفال والفروق الفردية بينهم. - - أن يراعى في تصميمها المتانة بحيث تتحمل الاستخدام لفترة معقولة. 
- - أن تكون سهلة الصيانة.

- - أن تكون جذابة للطفل وسهلة الاستخدام.

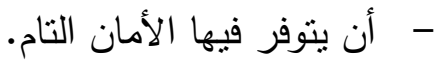

- - يفضل أن تعكس هذه الوسائل الثقافة المحلية ( هند ماجد ... . , . 1 1)

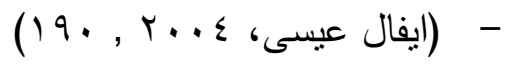

المهارات اللغوية لطقل الروضة:

تؤكد الاتجاهات الحديثة في تعليم اللغة على ضرورة الاهتمام بالارتباط الحاصل

بين مهارات اللغة، حيث إنها متداخلة بشكل كبير ويؤثر كل منها في غيرها، وعلى صلى

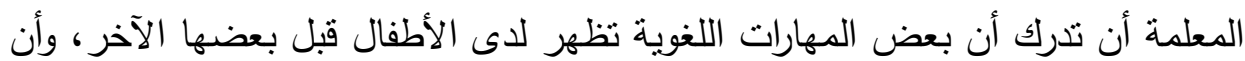

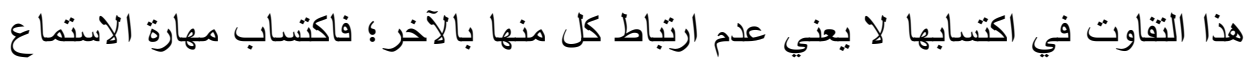

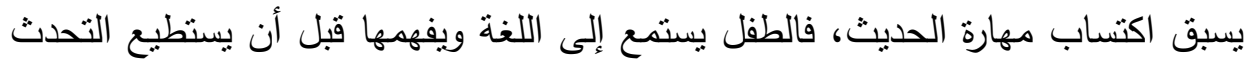
بها، وتعلم الاستماع والحديث يعتبران الأساس الذي تقوم عليه مهارتا القراءة والكتابة.

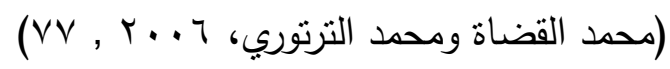

وتعليم الطفل مهارات القراءة يعتمد بشكل كبير على المفردات اللغوية للطفل وقدرته

على الحديث، فالكلمات التي لا تكون في حصيلة الطفل الثفوية، يصعب فهمها، وتصعب

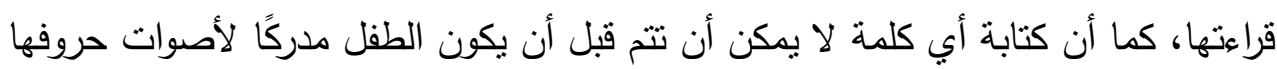

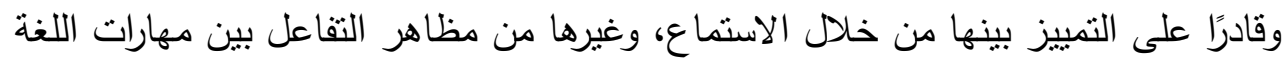

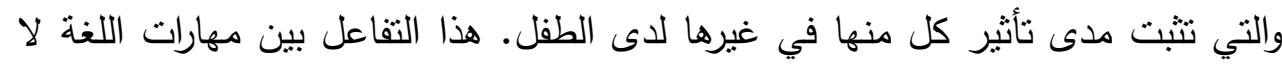
يمنع من التمبيز بينها، وفصل بعضها عن بعض من أجل فهمها وإدراك أهميتها والتخطيط

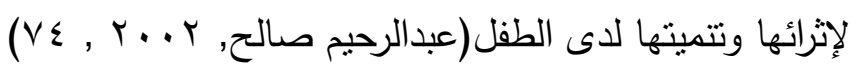

ويقصد بالمهارة في هذه البحث قدرة الطفل على القيام بأحد الأعمال اللازمة لإتمام

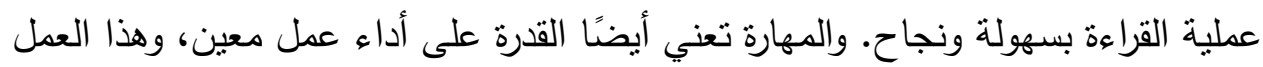

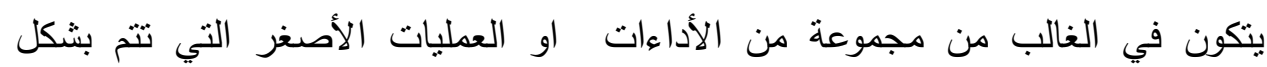




\section{مجلة " دراسات في الطقولة والتربية" - جامعة اسيوط}

متسلسل ومتتاسق فتبدو مؤتلفة مع بعضها البعض. والمهارات جزء مما يحتاج المتعلمون إلى تعلمه، وينبغي على المعلمين تدريسه، وهي تعتبر بعدًا هامًا من أبعاد البرامج

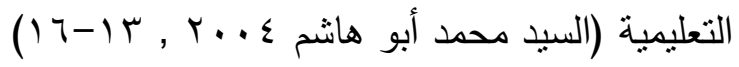

يعتبر عمر طفل ما قبل المدرسة العمر الذهبي لاكتساب المهارات، لان الطفل في

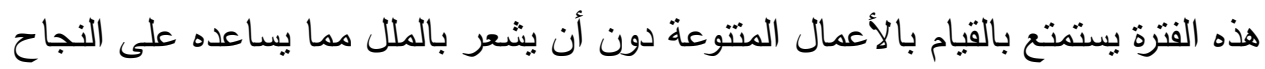

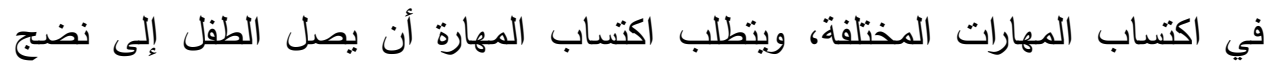
جسمي وعصبي مناسبين، وأن يكون الطفل راغبًا في تعلم المهارة، إضافة إلى تقديم التدريب المناسب مع التشجيع المستمر الذي يتيح الأداء السليم للمهارة مع الإشراف لهن

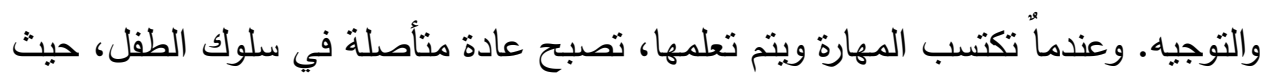
يقوم بها دون سابق تفكير في خطواتها ومراحلها (نبيل عبد الهادي، فاتن الصاحب، (1) , r... r

ويمكن تحديد معنى الاستعداد بأنه درجة تهيؤ الفرد للاستفادة من الخبرات التي

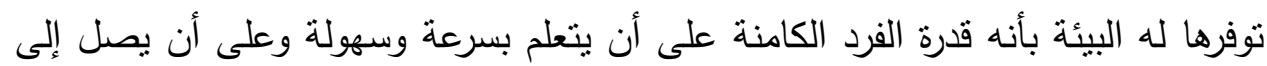

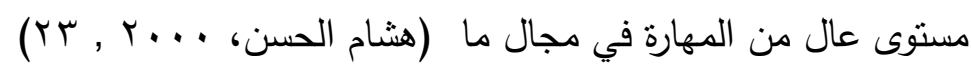
مفهوم الاستعداد للقراءة :

تتعدد وجهات النظر المتعلقة بتحديد مفهوم القراءة، حيث يختلف مفهوم القراءة باختلاف الباحث الذي يتصدى لدراستها. فعلماء اللغة يرون أن القراءة عملية إدراكية

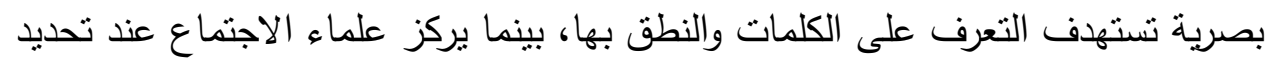

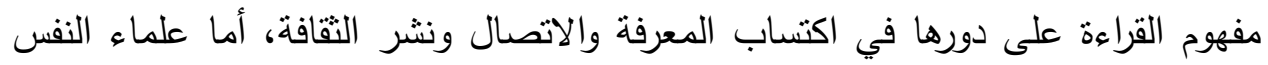
فيعرفون القراءة على أنها مجموعة من العمليات التفكيرية العقلية (فوقية حسن رضوانها

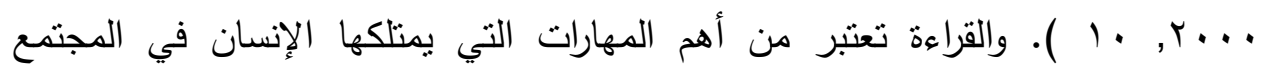

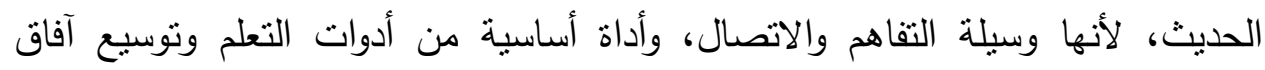

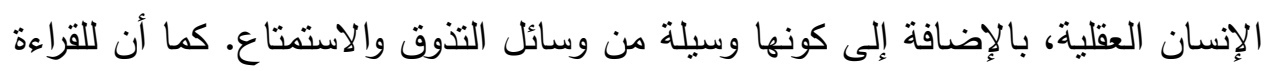

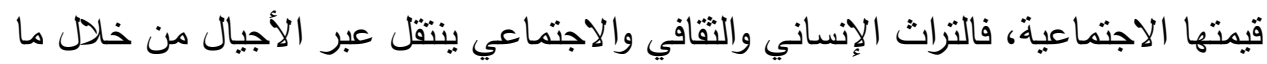


يدون وما يطبع من كتب .أنها "عملية التعرف على الرموز المطبوعة، ونطقها نطقًا صحيحًا (إذا كانت القراءة جهرية )، وفهمها"، وعلى هذا فهي عملية تشمل التعرف وهو

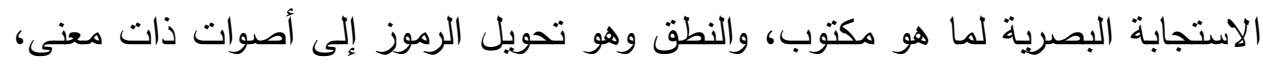

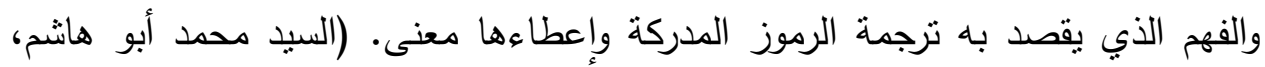
(I) Y. , r. E

إن قدرة الفرد على القراءة تعني قدرته على إتمام عملية معقدة تشترك في أدائها

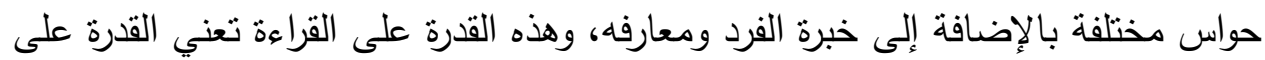
القيام بعدة مهام وهي رؤية الكلمات المكتوبة بشكل سليم, النطق بهذه الكلمات نطقًا

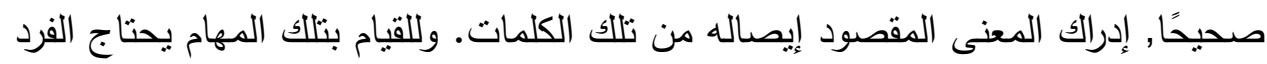

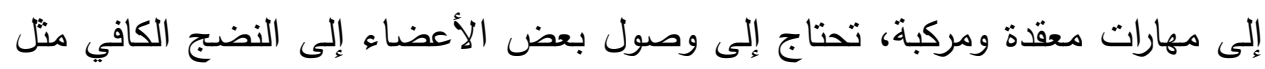
أعضاء البصر والسمع والنطق إضافة إلى الحاجة إلى تدريب وظائف هذه الأعضاء

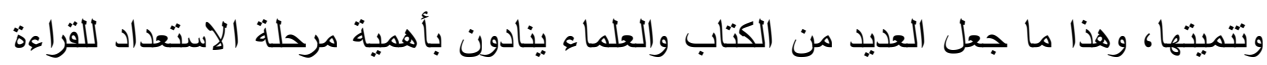
للطفل، وهي مرحلة يتلقى فيها الطفل الخبرة والتمرين الكافي ويكتسب فيها جميع المهارات اللازمة لإتمام عملية القراءة.

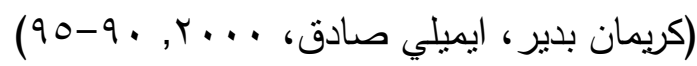

لذا فمن الواجب استغلال مرحلة الطفولة المبكرة في تكوين الاستعداد للقراءة عند الطفل، وذلك من خلال أنشطة وخبرات مدروسة تؤدي في النهاية إلى بناء مهارات القراءة، حيث يصل الطفل إلى مرحلة التعليم الأساسي وقد أثقن جميع المهارات الفرعية التي

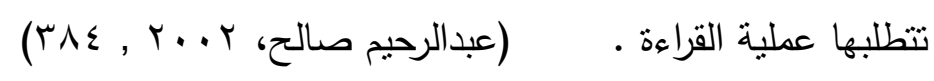

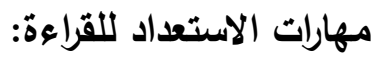

تعددت آراء الكتاب والباحثين حول المهارات الواجب إكسابها للطفل في مرحلة الاستعداد للقراءة، وحتى تتمكن الباحثة من تحديد هذه المهارات بشكل دقيق فقد اطلعت

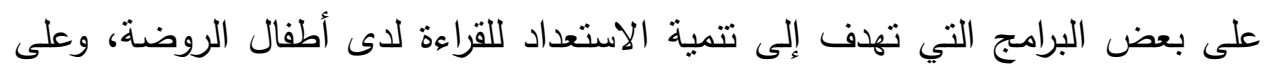

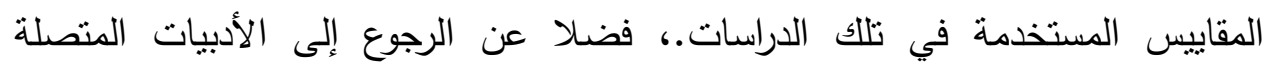




\section{مجلة " دراسات في الطقولة والتربية" - جامعة اسيوط}

بالموضوع. وقد استفادت الباحثة من ذلك في تحديد أهم مهارات الاستعداد للقراءة التي اتفقت عليها غالبية المصادر السابقة.

\section{ويمكن تصنيف هذه المهارات كما يلي:

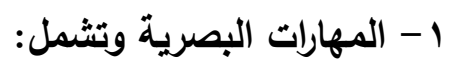

- - التعرف على أثكال بعض الحروف وأثنكال بعض الكلمات.

- التمييز البصري: ويشمل التمييز البصري بين المثيرات البصرية كالأشكال والألوان والأحجام وغيرها، والتمييز البصري بين أشنكال الحروف والكلمات.. - - التذكر البصري: تعني قدرة الطفل على الاحتفاظ في ذاكرته بما براه من مثيرات

$$
\text { بصرية. }
$$

- - التحرك البصري (الاتجاه البصري): وتعني قدرة الطفل على أن يتبع ببصره اتجاه

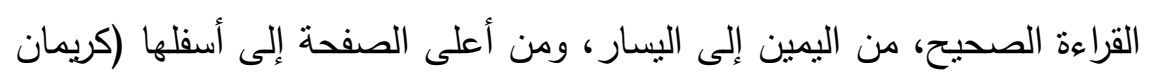

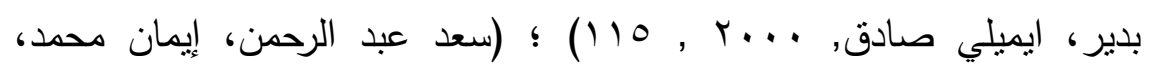

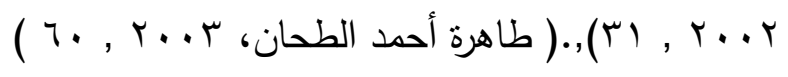

$$
\begin{aligned}
& \text { r - المهارات السمعية وتثمل: }
\end{aligned}
$$

- مهارة التمييز السمعي بين الأصوات المختلفة.

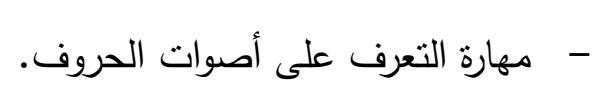

- مهارة التمييز السمعي بين أصوات الحروف وأصوات الكلمات.

- مهارة التذكر السمعي: وتساعد هذه المهارة الطفل على تذكر المثيرات السمعية

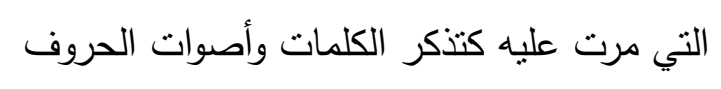

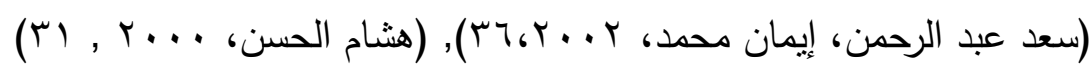

r- مهارات التحدث وتتضمن عدة مهارات وهي : 


\section{- - تتمية المفردات اللغوية التي يعرفها الطفل(القاموس اللغوي). - - القدرة على الحديث بجمل سليمة.}

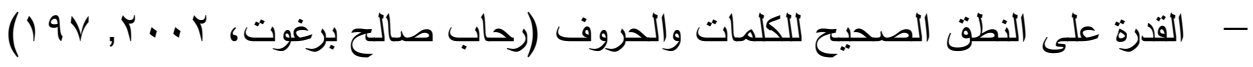
(عبد اللطيف حسين فرج، 0 . . r , 00)

\section{مهارات الاستعداد للقراءة التي تناولتها البحث الحالي}

على الرغم من أهمية جميع المهارات السابق ذكرها في تكوين استعداد الطفل

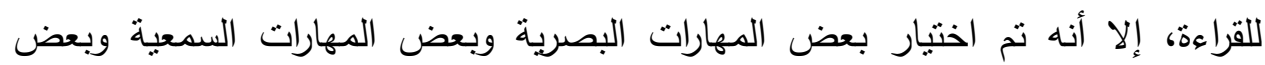
مهارات التحديث في البحث الحالي للتحقق من دور بيئة الروضة في تتميتها للطفل فبل

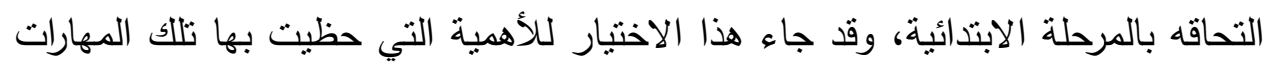

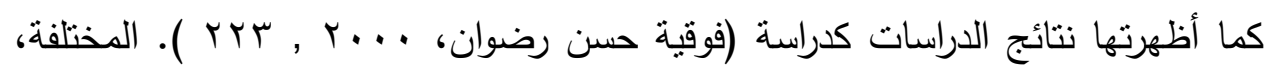
التي أثتتت وجود علاقة كبيرة بين كل من التمبيز السمعي والبصري وقدرة الطفل على تلى القراءة والتهجي كما اكدت بعض الدراسات على أن تعلم مهارات القراءة يعتمد على تتمية مهارات متعددة من بينها التمييز السمعي والتمييز البصري والتعبير الثفوي..(عبداللطيف

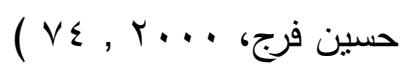

وفيما يلي تفصيل للمهارات التي تناولتها البحث الحالية:

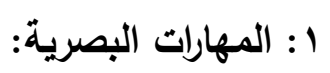

تتطلب عملية القراءة التعرف على أثنكال الحروف الأبجدية، كما تتطلب التمبيز بين الحروف وخاصة الحروف المتتابهة في الثكل، وتتطلب أيضا أن يدرك الطفل الكلمات

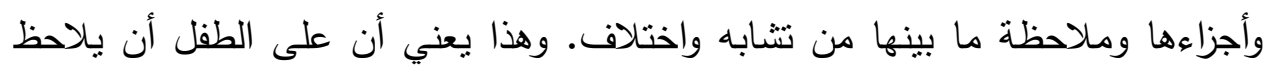

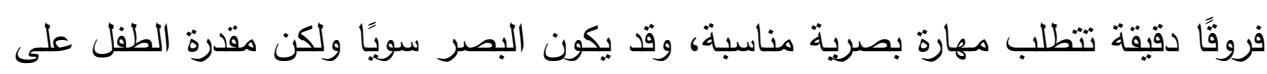

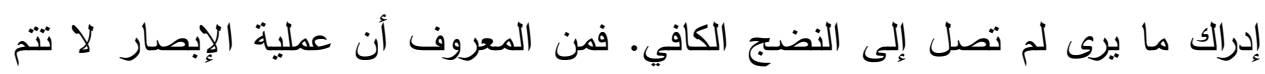
بمجرد رؤية الثيء بل لا بد من وجود نتسيق بين العينين حتى تمزجان الروئة وكأنها 


\section{مجلة " دراسات في الطقولة والتربية" - جامعة اسيوط}

عين واحدة، كما أن هناك بعض الصعوبات الثائعة بين الأطفال في طفولتهم المبكرة،

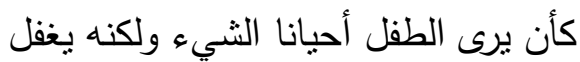

تفاصيله، فيركز في رؤيته على الثكل العام أو اللون أو الحجم ولا يركز على العناصر الأخرى التي يتكون منها الثكل. وهنالك مشكلة شائعة بين الأطفال عند بداية

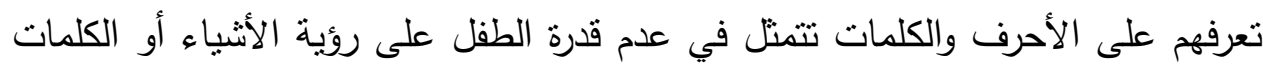

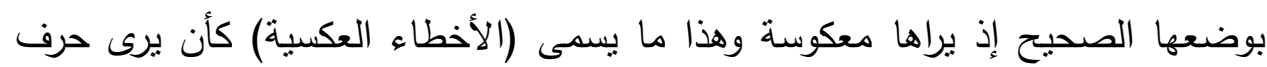

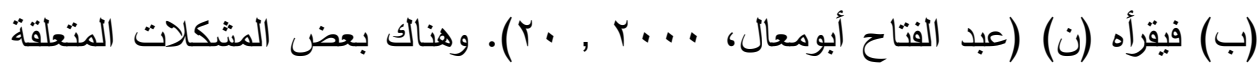
بأثكال الحروف الهجائية، حيث إن هناك حروفًا في اللغة العربية متتابهه في شكلها

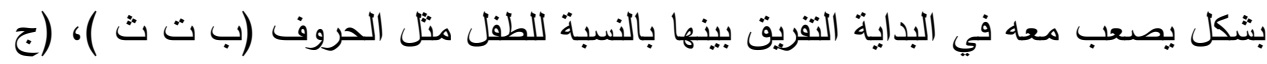

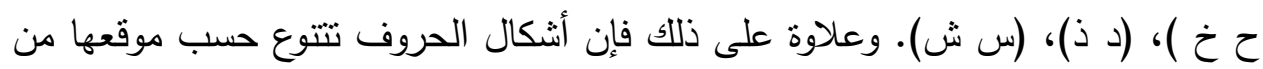
الكلمة مما يشكل صعوبة على الطفل في التعرف عليها. وتزول جميع هذه المظاهر

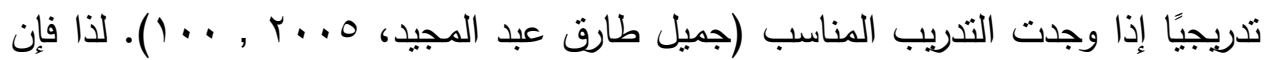
الطفل بحاجة إلى أن يمر بمجموعة من الخبرات والتمارين التي تساهم في إكسابه المهارات البصرية اللازمة لتعلم القراءة، ومنها مهارات التمييز البصري بين الأشكال

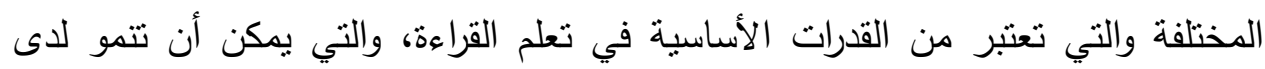
الطفل من خلال مطابقة الأشكال، وتتظيم الأشياء في نسلسل معين، وتركيب الصور المجزأة وغيرها وكذلك يجب أن نقدم للطفل الوسائل والأنشطة التي نساعده على التعرف على أثنكال الحروف، وتمييز أوجه الثبه والاختلاف بين الحروف والكلمات (نايف

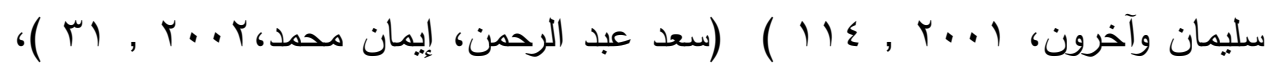
حيث إن عملية القراءة تعتمد بشكل أساسي على هذه القدرة.

وعند تدريب الأطفال على التمبيز البصري بين الكلمات بفضل البدء بالكلمات

التي تكون الفروق بينها كبيرة وبعدها يمكن الانتقال إلى الكلمات التي بينها فروق صغيرة ليني

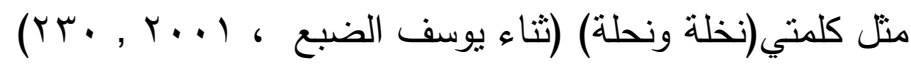
ومما سبق يمكن تحديد المهارات البصرية التي تتاولها البحث الحالي بما يلي: 
1- مهارة التعرف على أنثكال بعض الحروف المنفصلة والمتصلة. r - مهارة التمييز البصري بين المثيرات البصرية المختلفة كالأشكال والأحجام. r- مهارة التمييز البصري بين أثنكال الحروف والكلمات.

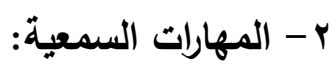
الاستماع مهارة لغوية هامة لها تأثير مباشر على المهارات اللغوية الأخرى. فالاستماع عامل حاسم في ظهور النطق عند الطفل، ويتطور نطق وكلام الطفل حتى لهى

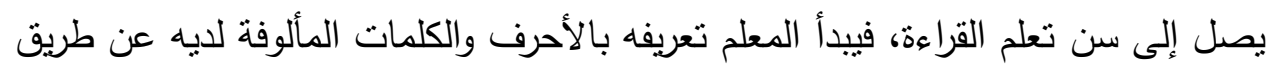

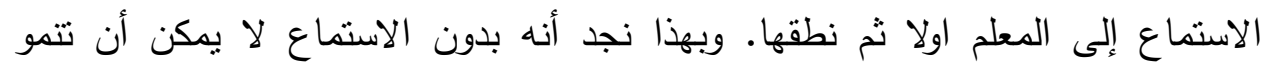
مهارات اللغة الأخرى بشكل سليم وإذا عجز الطفل عن الاستماع السليم، فإنه سيجد صعوبة فى ربط الأصوات التي يسمعها بالكلمات التي براها، كما سيجد صعوبة في تعلم النطق السليم للأحرف والكلمات، وفي اتباع توجيهات من يقومون بتعليمه، مما يعرضد للصعوبات أثناء تعلم القراءة التي قد يسفر عنها توتز انفعالي وضيق. وقد يكون الطفل

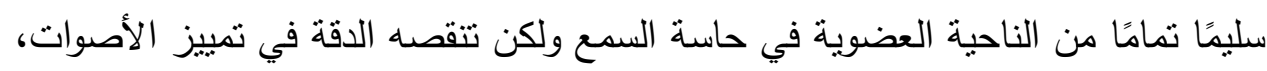
وتمبيز المتثابه والمختلف منها، مما يحول دون نجاحه في تعلم القراءة ـ (أحمد عبداله.،

$$
\text { فهيم مصطفى، .... }
$$

وفي المقابل تجد أن الأطفال الذين لديهم مهارات تمييز سمعي عالية يكون لديهم

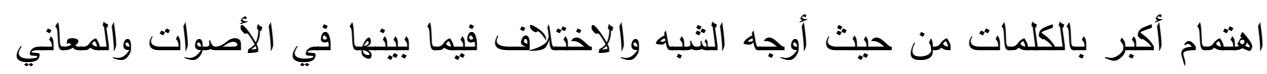
مما يمكنهم من تعلم القراءة بيسر ونجاح. ورغم أن بعض الأطفال يكتسبون مهارة التمبيز

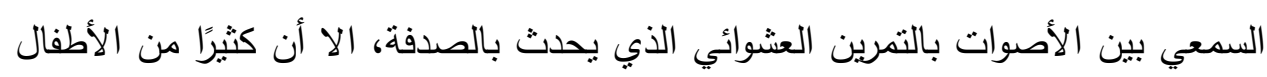
يحتاجون إلى بعض الأنشة المخططة التي تهدف إلى تحسين مهاراتهم السمعية

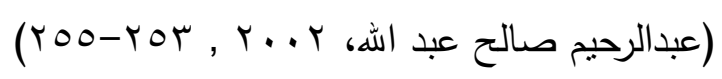

حيث إن المهارات السمعية لا تعتمد على الأذن فقط بل إنها تتطلب نشاطًا ذهنيا يتم من

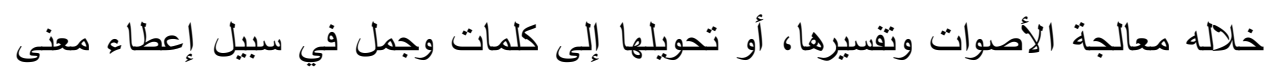

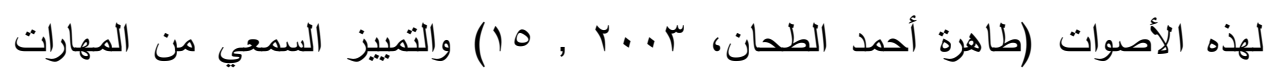




\section{مجلة " دراسات في الطقولة والتربية" - جامعة اسيوط}

السمعية التي تبدأ عند الطفل بالتعرف على عالم الأصوات المحبطة به منل أصوات أفراد الأسرة وأصوات الأدوات المنزلية وأصوات الطيور والحيوانات وأصوات الظواهر الطبيعية وغيرها. وبعد ذلك يمكن توجيه الطفل إلى التمبيز بين الفروق بين الأصوات كالتمييز بن

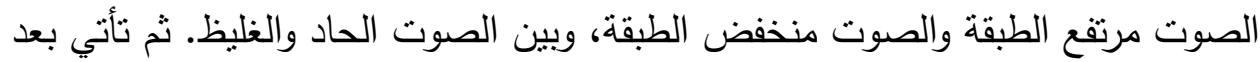

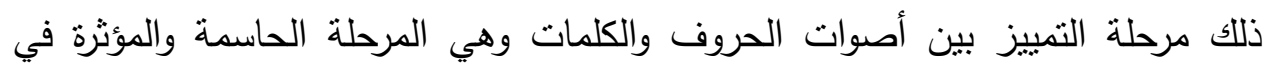

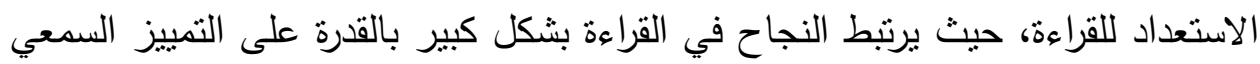
بين أصوات الحروف المختلفة والمتقاربة في النطق، وكذلك قدرة الطفل على التمبيز السمعي بين أصوات الكلمات من حيث بدايتها ونهايتها الصوتية، والتمييز السمعي بين وكين ولينه

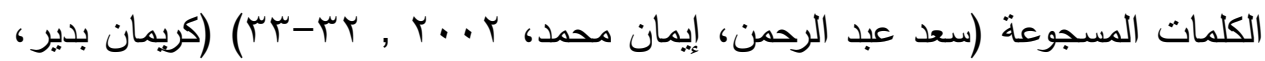
ايميلي صادق، ... . . . (1).

وهذه المهارات تساعد الطفل على إدراك أهمية الأصوات المختلفة التي تتكون

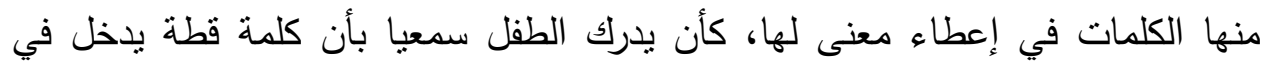

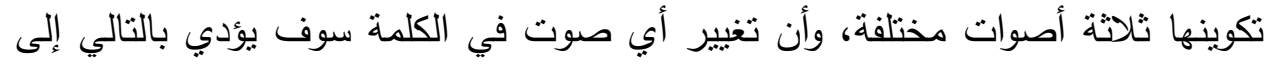
تغيير الكلمة بكاملها وتغيير معناها، فعلى سبيل المثال فإن تغيير الصوت الأول من كلمة قطة إلى صوت الحرف(ب)، سوف يغيرها بالتالي إلى كلمة (بطة) وهي كلمة مختلفة

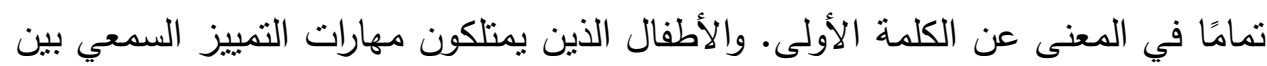
أصوات الحروف والكلمات تزيد احتمالات نجاحهم في المستقبل في تعلم القراءة، لارتباطها بقدرة الأطفال على تهجي الكلمات وربط الحروف بأصواتها، وفي المقابل فإن الأطفال الذين لا تتاح لهم الخبرات الكافية التي تمكنهم من اكتساب هذه المهارات يكونون أكثر

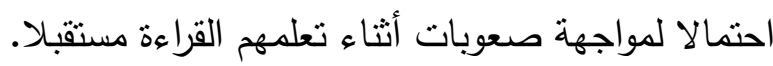

(Pullen \& Justic, 2003,) ,( U.S Department of education, 2001) ومما سبق يمكن تحديد المهارات السمعية التي تناولها البحث الحالي بما يلي: التمييز السمعي بين أصوات الحروف و التمييز السمعي بين أصوات الكلمات من حيث بدايتها ونهايتها الصوتية، والتمييز السمعي بين الكلمات المسجوعة. 


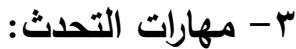

يؤثر عدد المفردات التي يفهمها الطفل ويستخدما في حديثه بشكل كبير عند تعليم الطفل للقراءة، فقراءة الكلمات التي يعرفها يكون أسهل بالنسبة إليه من قراءة الكلمات

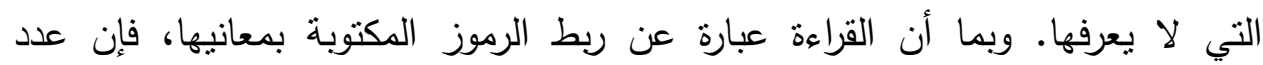

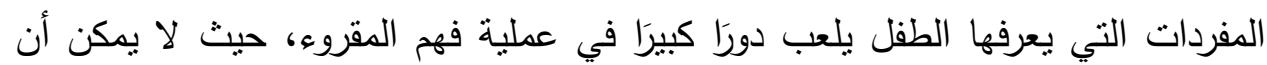

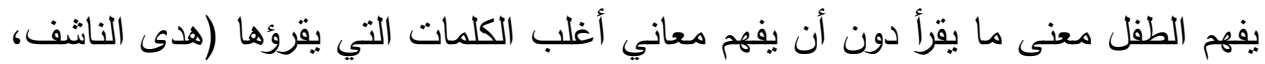
$(r \vee-r q, r \ldots$

وتؤثر كذللك قدرة الطفل على الحديث في عبارات تتصف بالبساطة والدقة على قدرته

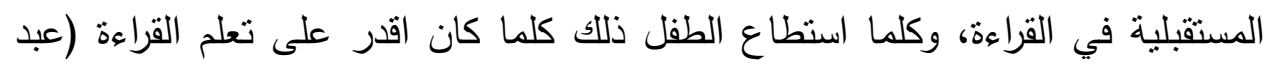

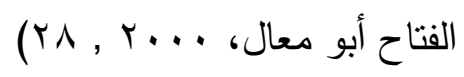

وقد أظهرت بعض الدراسات التنبؤية أن قدرات أطفال الروضة اللغوية والتي تتمتل في محصول الطفل اللفظي، والتحدث بجمل سليمة تعد عاملا مؤثرًا بشكل كبير على

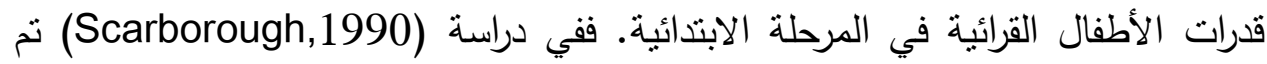
تتبع or طفلا من عمر السنتين إلى الصف الثاني الابتدائي، وقيست قدرات الأطفال الثفهية من سن سنتين إلى خمس سنوات، ومن بين تللك القدرات معرفة عدد كبير من

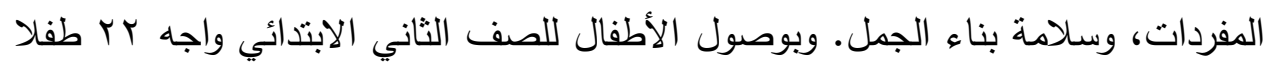
من هؤلاء الأطفال صعوبات في القراءة، وبالرجوع إلى تقويم مهارات اللغة الثفهية لهؤلاء الأطفال من سن سنتين إلى خمس سنوات، تبين أنهم قد أظهروا ضعفا في مهارات اللغة

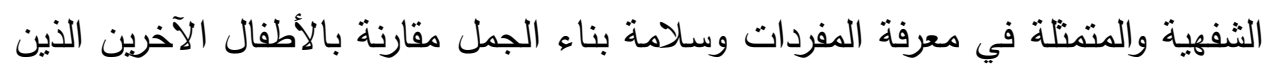
لم يواجهوا أية صعوبات في القراءة. (pullen \& Justic , 2003, 90) ومما سبق يمكن تحديد مهارات التحدث التي تناولها البحث الحالي بما يلي: 


\section{مجلة " دراسات في الطفولة والتربية" - جامعة اسيوط}

1 - تتمية حصيلة الطفل من المفردات اللغوية.

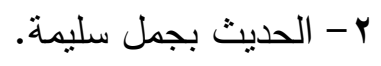

اسئلة البحث

يسعى البحث الحالي إلى الإجابة على السؤال التالي :

ما علاقة بيئة الروضة بتتمية بعض مهارات الاستعداد للقراءة للأطفال؟

ويتفرع من هذا السؤال الرئيس الأسئلة الفرعية التالية:

- ما مدى نوافر الوسائل والتجهيزات الصفية في تتمية بعض مهارات الاستعداد

للقراءة للأطفال؟ مدو نو

- ما مدى نوافر الانشطة الصفية المستخدمة من قبل المعلمة لتتمية مهارات

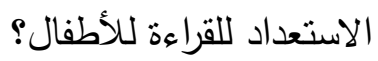

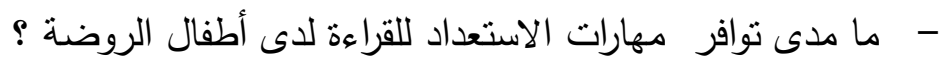

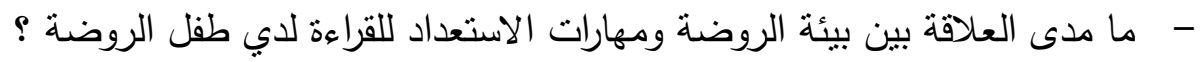

أدوات البحث مدى

- الاستبانة الموجهة للمعلمات للتعرف على درجة ممارستهن للأنشطة التي تتمى مهارات الاستعداد للقراءة لدى الأطفال (اعداد الباحثة )

- - بطاقة الملاحظة المستخدمة لملاحظة الوسائل في بيئة الروضة التي تتمي مهارات الاستعداد للقراءة لدى الأطفال اعداد الباحثة)

- - اختبار مهارات الاستعداد للقراءة لدى طفل الروضة (اعداد الباحثة)

$$
\text { اولا: الاستبانة }
$$

(1) (1) (1) : تصميم الاستبانة:

قامت الباحثة بعد الاطلاع على الدراسات السابقة المشابهة والأدبيات ذات العلاقة

بتصميم استبيان نم توجيهه إلى معلمات رياض الأطفال لمعرفة دور المعلمات في إكساب الابل 
الأطفال بعض مهارات الاستعداد للقراءة. وقد اشتملت الاستبانة على ثلاثة محاور: المحور الأول خاص بالمهارات البصرية، والمحور الثاني خاص بالمهارات السمعية،

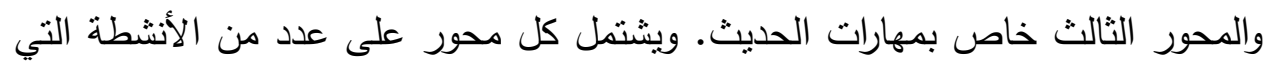

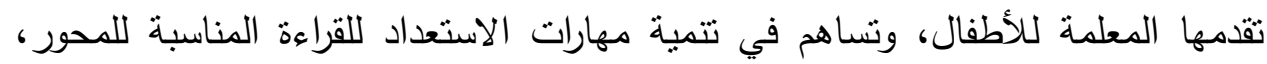
وطلب من المعلمات تحديد درجة تطبيقهن منل تلك الأنشطة مع الأطفال وفق تدرج (درجة عالية، درجة منوسطة، درجة منخفضة)، وأعطيت للاستجابات درجات على التوالي

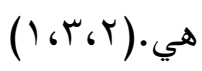

(r) (r) صدق الاستبانة: (ب)

\section{اعتمدت الباحثة في حساب صدق الاستبانة على ما يلي:}

Logical Validity (الصدق المنطقي ( صدق المحكمين -

تم عرض الصورة الأولية للاستبانة على مجموعة من السادة المحكمين

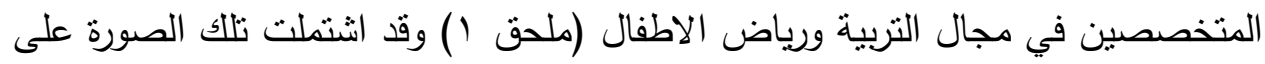

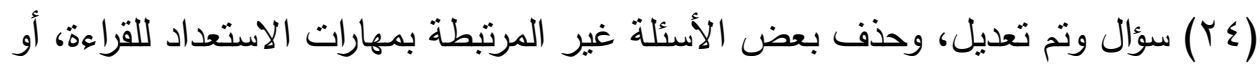
غبر مناسبتها لطبيعة وخصائص الاطفال

- وفي ضوء آراء السادة المحكمين تم تعديل، وحذف بعض الفقرات ؛ لتكرار بعضها ولعدم مناسبتها لطبيعة وخصائص العينة، والتي لم تحظ بنسبة اتفاق

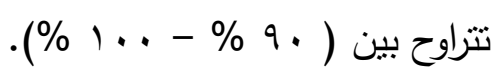

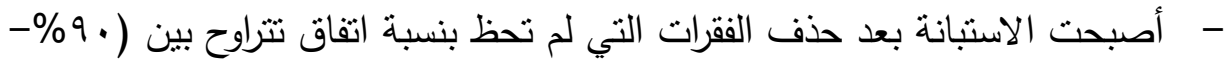

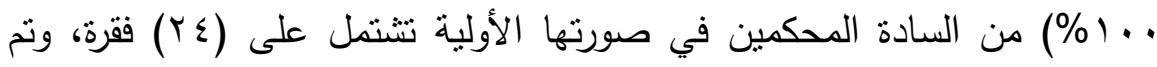
تطبيقها على عينة الدراسة الاستطلاعية للاستقرار على الصورة النهائية.

- - الصدق التمييزي:

ويتم حساب الصدق التمييزي للاستبانة عن طريق حساب دلالة الفروق بين

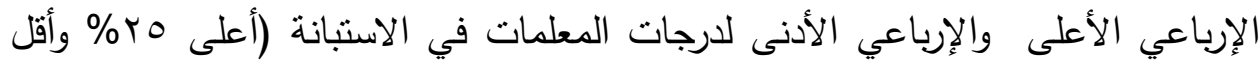




\section{مجلة " دراسات في الطقولة والتربية" - جامعة اسيوط}

•r\%)، وتم حساب دلالة الفروق بين الإرباعي الأعلى والأدنى عن طريق حساب اختبار مان ويتتي لدلالة الفروق بين رتب متوسطي درجات المعلمات في المجموعتين العليا والدنيا، وجدول ( ) يوضح ذلك.

جدول( 1 ): متوسط ومجموع الرتب وقيمة Z ومستوى الدلالة

للفرق بين الإرباعي الأعلى والأدنى لارجات المعلمات في الاستبانة

\begin{tabular}{|c|c|c|c|c|c|}
\hline مستوى الدلالة & قيمة Z & مجموع الرتب & مثوبط الرتب & العدد & الارباعيات \\
\hline \multirow{2}{*}{$\cdots \cdot 1$} & \multirow{2}{*}{ r.VY- } & rq.rA & דצ. & $\wedge$ & الارباعي الأدنى \\
\hline & & AV.IY & $1 . .19$ & $\wedge$ & الارياعي الأعلى \\
\hline
\end{tabular}

يتضح من جدول(r) أن قيمة Z دالة عند مستوى دلالة ا +...مما يؤكد ارتفاع

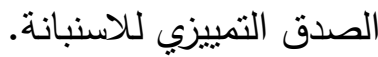

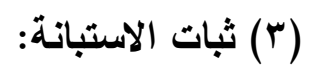

: Alpha Cronbach Method طريقة ألفا كرونباك -

استخدمت الباحثة معادلة ألفا كرونباك وهي معادلة تستخدم لإيضاح المنطق العام لثبات الاختبارات، وبلغت قيمة معامل ثبات الاستبانة ؟rی.. . وهي قيمة مرتفعة

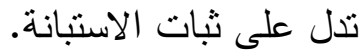
- طريقة إعادة التطبيق: - - مبيق استخدمت الباحثة طريقة إعادة التطبيق لحساب ثبات الاستبانة بعد تطبيقها على

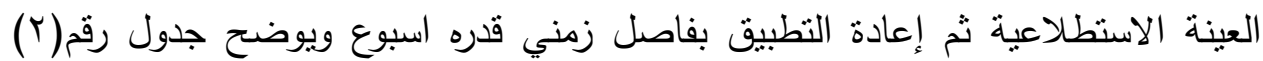
معاملات ثبات إعادة النطبيق ودلالتها.

جدول(r): معاملات ثبات إعادة التطبيق للاستبانة

\begin{tabular}{|c|c|c|c|}
\hline كرونباك & مستوى الدلالة & معامل بيرسون لإعادة التطبيق & 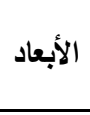 \\
\hline. .117 & $\cdots 1$ &..$\wedge 9 r$ & 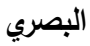 \\
\hline
\end{tabular}




\begin{tabular}{|c|c|c|c|}
\hline كرونباك ألفا & مستوى الدلالة & معامل بيرسون لإعادة التطبيق & الأبعاد \\
\hline ..Arr & $\cdots 1$ &..$\wedge 97$ & تعدث \\
\hline.$\wedge 1$ & &. .179 & سمعي \\
\hline . . Art & $\ldots 1$ &.$\wedge \vee \wedge$ & درجة البطاقة الكلية \\
\hline
\end{tabular}

يتضح من جدول(ا) أن معاملات ثبات إعادة النطبيق للاستبانة دالة عند مستوى دلالة ا . .. مما يؤكد ارتفاع معاملات ثبات الاسنبانة.

ثانيا: بطاقة الملاحظة (1) - تصميم بطاقة الملاحظة:

تحقيقًا لأهداف الدراسة، تم تصميم بطاقة ملاحظة للوسائل والتجهيزات الصفية في

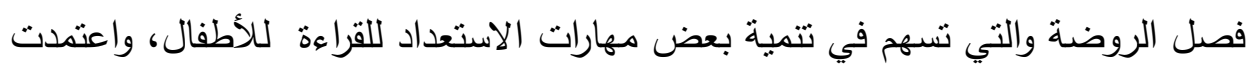
الباحثة في تصميمها على: 1- المراجع العلمية ذات الصلة بموضوع البحث. r- الدراسات السابقة ذات الصلة بموضوع البحث. r- الزيارات الميدانية الاستطلاعية التي قامت بها الباحثة لبعض الروضات التابعة

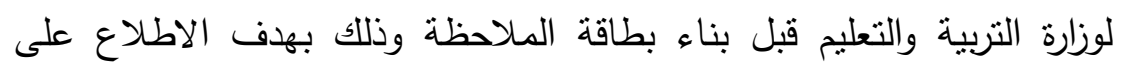
الوسائل الموجودة في هذه الروضات. وقد شملت البطاقة ب محاور رئيسة اشتملت على أهم الوسائل والتجهيزات الصفية التي تساهم في تتمية الأطفال

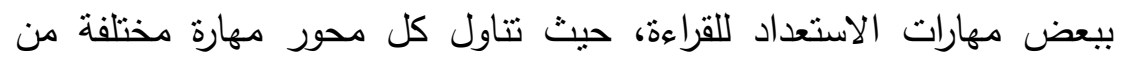

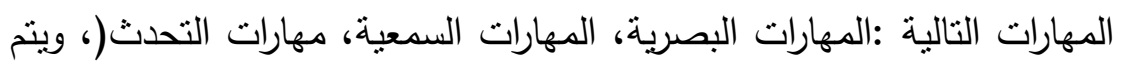
تسجيل درجة نوافر كل وسيلة وفق تدرج ثلاثي وهو (متوفر، منوفر بدرجة

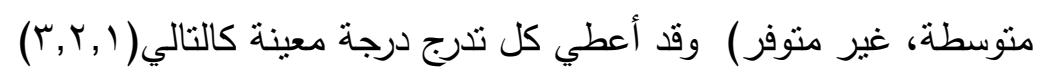




\section{مجلة " دراسات في الطقولة والتربية" - جامعة اسيوط}

(r) (r) صدق بطاقة الملاحظة

اعتمدت الباحثة في حساب صدق البطاقة على ما يلي:

- الصدق المنطقي ( صدق المحكمين )

تم عرض الصورة الأولية للبطاقة على مجموعة من السادة المحكمين المتخصصين، وقد اثتملت تلك الصورة على (ب0) سؤال بهدف: التأكد من مناسبة الأسئلة

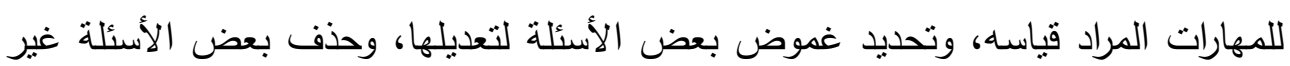

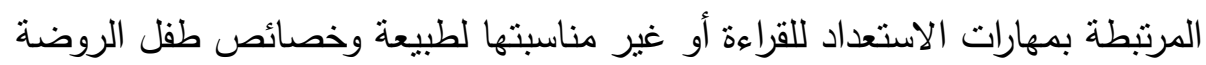

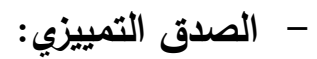

ويتم حساب الصدق التمييزي للبطاقة عن طريق حساب دلالة الفروق بين

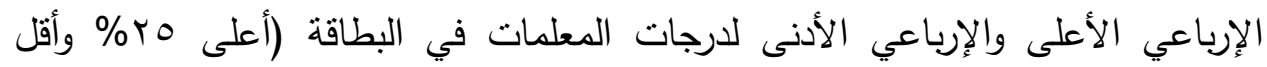

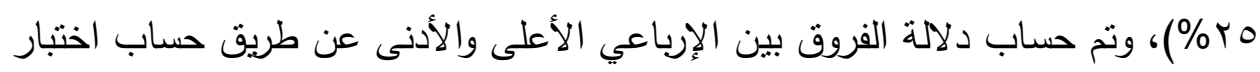

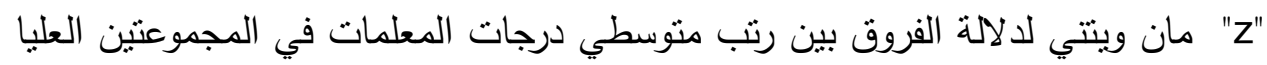
والدنيا، وجدول (r) يوضح ذلك.

جدول(r): متوسط ومجموع الرتب وقيمة Z ومستوى الدلالة

للفرق بين الإرياعي الأعلى والأدنى لارجات المعلمات في البطاقة

\begin{tabular}{|c|c|c|c|c|c|}
\hline مستوى الدلالة & قيمة Z & مجموع الرتب & متوسط الرتب & العدد الع & الارباعيات \\
\hline \multirow{2}{*}{$\ldots 1$} & \multirow{2}{*}{ r.7^- } & $r . .$. & r.vo & $\wedge$ & الارباعي الأدنى \\
\hline & & ^०. $\leqslant \leqslant$ & $1 . .71$ & $\wedge$ & الارياعي الأعلى \\
\hline
\end{tabular}

يتضح من جدول(r) أن قيمة Z دالة عند مستوى دلالة ا +...مما يؤكد ارتفاع الصدق التمييزي للبطاقة. 


\section{( ) بات بطاقة الملاحظة}

- Alpha Cronbach Method طريقة ألفا كرونباك -

استخدمت الباحثة معادلة ألفا كرونباك وهي معادلة تستخدم لإيضاح المنطق العام

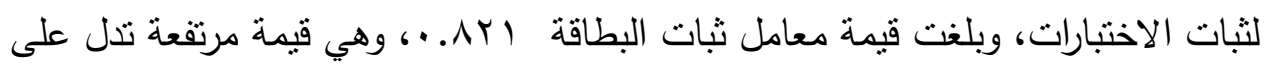

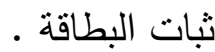

- طريقة إعادة التطبيق: - - مبيق

استخدمت الباحثة طريقة إعادة التطبيق لحساب ثبات البطاقة بعد تطبيقها على

العينة الاستطلاعية ثم إعادة التطبيق بفاصل زمني قدره اسبوع ويوضح جدول رقم(ع ) ) معاملات ثبات إعادة التطبيق ودلالتها.

جدول(ء): معاملات ثبات إعادة التطبيق لبطاقة الملاحظة

\begin{tabular}{|c|c|c|c|}
\hline ألفا كرونباك & مستوى & معامل بيرسون & الأبعاد \\
\hline r. & $\ldots 1$ & - . 1980 & البصري \\
\hline DAro & $\ldots 1$ & - . & تحدث \\
\hline . .AT. & $\ldots$ &..$\wedge \vee \wedge$ & سمعي \\
\hline ..Ar & $\ldots 1$ & $\therefore \wedge \vee \wedge$ & درجة البطاقة الكلية \\
\hline
\end{tabular}

يتضح من جدول(ع) أن معاملات ثبات إعادة التطبيق لبطاقة الملاحظة دالة عند

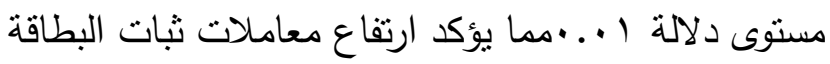

ثالثا: اختبار مهارات الاستعداد للقراءة لدى طفل الروضة

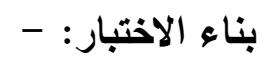

- الاطلاع على بعض الدراسات السابقة التي قامت بتصميم اختبارات مهارات

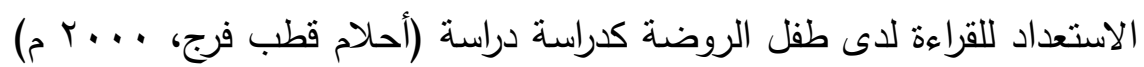

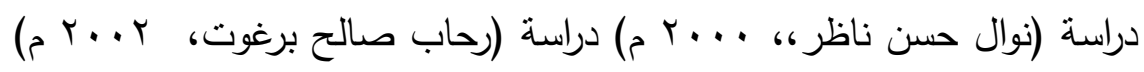




\section{مجلة " دراسات في الطقولة والتربية" - جامعة اسيوط}

دراسة (إيمان أحمد خليل، ب... م م) ودراسة (Elsea, 2001) ودراسة

(Fuchs et al ,2001)

- الاطلاع على المقاييس والاختبارات والادوات التي تتاولت مهارات الاستعداد للقراءة لدى طفل الروضة - صياغة عبارات الاختبار على شكل مجموعة من الصور المختلفة والمنتمية للمهارات المستهدف تتميتها في البحث الحالي (مهارات بصرية - مهارات سمعية- مهارات تحدث واعطى لكل مهارة خمس اسئلة ولكل سؤال بدائل مصورة وعلى الطفل ان يختار البديل الصحيح من البدائل التىى ونى امامه - تصميم هذه البدائل بحيث تكون احد هذه البدائل يعبر عن المهارة

الهذف من الاختبار :

قياس مدى تمكن الاطفال من مهارات الاستعداد للقراءة وصف الاختبار :

هو اختبار مصور مكون من (ץ) ابعاد( البعد البصري - البعد السمعي - بعد التحدث ) ولكل بعد( ) اسئلة ولكل سؤال بدائل , ينم عرض الاختبار على الطفل ويتم تسجيل اجابة كل طفل على حدى في استمارة خاصة به تصحيح الاختبار :

مجموعة اسئلة الاختبار (10 ) سؤال ويعطى الطفل درجة واحدة في حالة اختيار البديل الصحيح وصفر في حالة اختيار البديل الخاطئة وبذلك فان اعلى درجة يحصل عليها الطفل في هذا الاختبار (10 ) درجة واقل درجة( صفر) وذلك طبقا للأساليب الاحصائية.

عرض الصورة الاولية للاختبار على مجموعة المحكمين وتم اجراء مناقثة

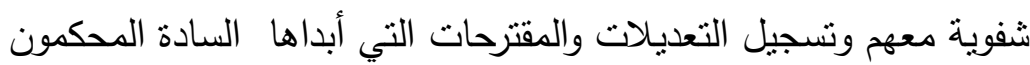

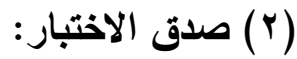

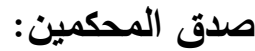

- تم عرض الصورة الأولية للاختبار على مجموعة من السادة المحكمين المتخصصين وفي ضوء آراء السادة المحكمين نم تعديل وحذف بعض الفقرات؛ لتكرار بعضها 
ولعدم مناسبتها لطبيعة وخصائص العينة، والتي لم تحظ بنسبة اتفاق تتراوح بين

$$
\text { . (\% 1... - \% .) }
$$

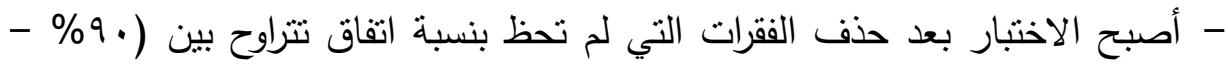

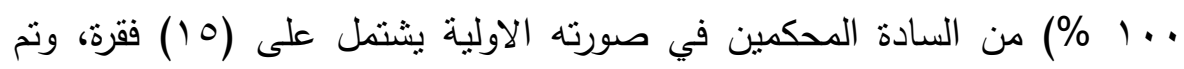
تطبيقه على عينة الدراسة الاستطلاعية للاستقرار على الصورة النهائية للاختبار .

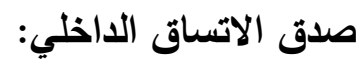
للاطمئنان على صدق الاتساق الداخلي للاختبار تم تطبيق الاختبار على عينة استطلاعية قدرها ·.بطل، وتم حساب معامل ارتباط بيرسون بين كل فقرة من فقرات

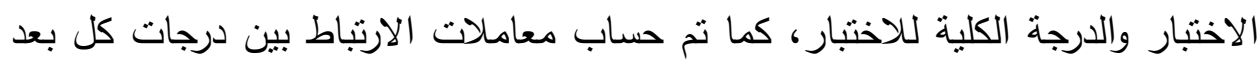
والدرجة الكلية على الاختبار كما هو موضح بالجدول التالي: - - - - الصدق التمييزي: ويتم حساب الصدق التمييزي للاختبار عن طريق حساب دلالة الفروق بين

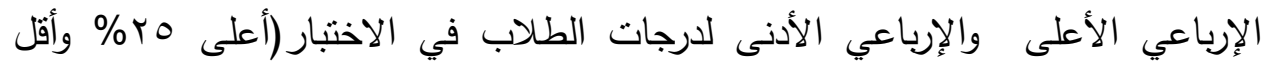

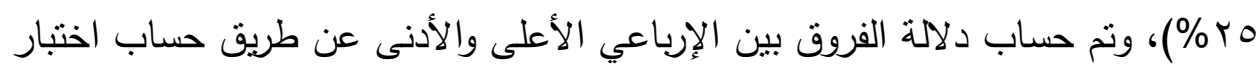

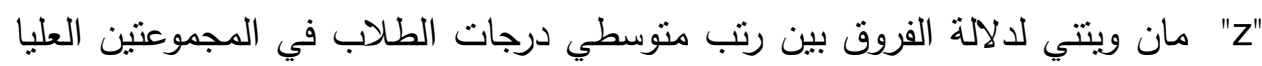
والدنيا، وجدول (0) يوضح ذللك.

جدول(ه): متوسط ومجموع الرتب وقيمة Z ومستوى الدلالة للفرق بين الإرياعي الأعلى والأدنى لارجات الطلاب في الاختبار

\begin{tabular}{|c|c|c|c|c|c|}
\hline مستوى الدلالة & قيمة Z & مجموع & متوسط & العدد العد & الارباعيات \\
\hline \multirow{2}{*}{$\cdots 1$} & \multirow{2}{*}{ r.^৭- } & r.... & $\varepsilon .0$. & $\wedge$ & الارياعي الأدنى \\
\hline & & $9 \leq \ldots 1$ & 11.87 & $\wedge$ & الارياعي الأعلى \\
\hline
\end{tabular}

بتضح من جدول(r) أن قيمة z دالة عند مستوى دلالة ا +...مما يؤكد ارتفاع

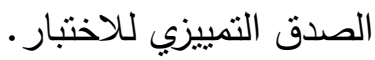




\section{مجلة " دراسات في الطقولة والتربية" - جامعة اسيوط}

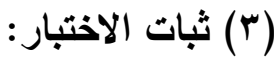

\section{: Alpha Cronbach Method طريقة ألفا كرونباك - لاكباك -}

استخدمت الباحثة معادلة ألفا كرونباك وهي معادلة تستخدم لإيضاح المنطق

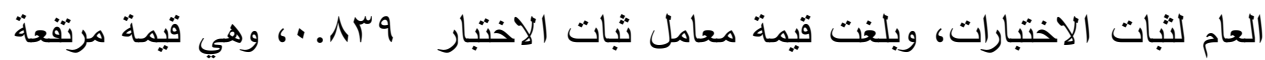

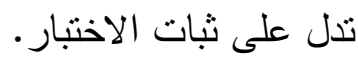

- طريقة إعادة التطبيق: - - مبي:

استخدمت الباحثة طريقة إعادة التطبيق لحساب ثبات الاختبار بعد تطبيقه على

العينة الاستطلاعية ثم إعادة التطبيق بفاصل زمني قدره اسبوعين ويوضح جدول رقم(آ) معاملات ثبات إعادة التطبيق ودلالتها.

جدول(؟): معاملات ثبات إعادة التطبيق اختبار مهارات الاستعداد للقراءة

\begin{tabular}{|c|c|c|c|}
\hline ألفا كرونباك & الدلالة & لإعادة التطبيق & الأبعاد \\
\hline$. \wedge \leqslant 0$ & $\ldots 1$ &.$\wedge \vee 4$ & البصري \\
\hline . DrT & $\ldots 1$ & $\therefore \wedge \vee \wedge$ & تحدث \\
\hline . Arv & $\ldots 1$ & $\cdot . \wedge \wedge 9$ & سمعي \\
\hline . . Arq & $\ldots 1$ &..$\wedge \wedge \mathrm{V}$ & درجة الاختبار الكلية \\
\hline
\end{tabular}

يتضح من جدول(Y) أن معاملات ثبات إعادة النطبيق لاختبار مهارات الاستعداد

للقراءة. دالة عند مستوى دلالة ا .. . مما يؤكد ارتفاع معاملات ثبات الاختبار. اجراءات البحث

بعد التأكد من صدق وثبات أدوات البحث، قامت الباحثة بما يلي: 1- توزيع الاستبانات على معلمات الروضات الحكومية بمدينة أسيوط، وذللك بوضع كل مجموعة من الاستبانات في ظرف خاص موضح عليه اسم الروضة، ثم قامت الباحثة بنسليمه شخصيًا للمعلمات .. 
r- زيارة الروضات التي نم اختيارها من ضمن العينة لتطبيق أداة ( بطاقة ملاحظة الوسائل والتجهيزات الصفية )، حيث قامت الباحثة بزيارة الفصول في كل كل

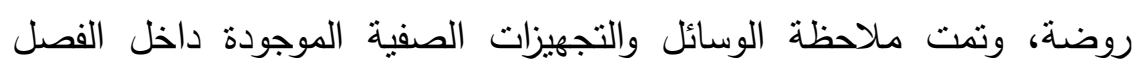
والتي يتفاعل الطفل مع معظمها خلال فترة( اللعب الحر في الأركان التعليمية). وراعت الباحثة أن تكون هذه الزيارات في وحدات تعليمية مختلفة لتلاحظ بشكل أفضل تغير الأدوات والوسائل فيها. وقد اهتمت الباحثة بنسجيل

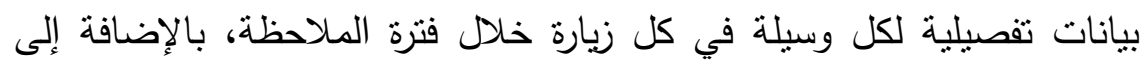
مناقشة المعلمات والمشرفات في الروضات حول بعض الوسائل ودرجة نوفرها في لي ليات الروضة، وذلك بهدف القيام بالملاحظة بشكل موضوعي قدر الإمكان. r- استلام الاستبانات بعد تعبئتها من أفراد عينة البحث حيث بلغ عدد ع - الاستبانات (• (1) روضات بواقع (0) قاعات و (0) طفل و (0 ) معلمة ه- تطبيق اختبار مهارات الاستعداد للقراءة على الاطفال في القاعات التي تم زيارتها צ- رصد الدرجات ومعالجتها احصائيا تتائج البحث لتحقيق أهداف البحث وفي ضوء منهج وعينة البحث وعلى ضوء ما أسفرت عنه المعالجات الإحصائية، تعرض الصفحات القادمة ما نم من نتائج تقوم الباحثة بعرضها

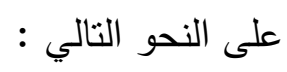

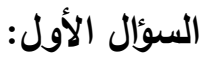

للإجابة عن السؤال الاول والذي ينص على " ما مدى نوافر الوسائل والتجهيزات في

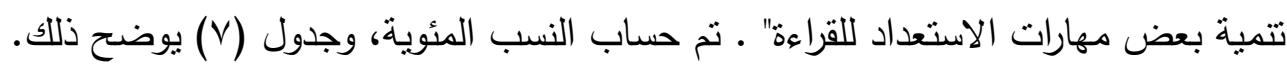


مجلة " دراسات في الطفولة والتربية" - جامعة اسيوط

جدول(V): النسب المئوية لملاحظة الباحثة على الوسائل والتجهيزات

المتوافرة داخل قاعات الروضة

\begin{tabular}{|c|c|c|c|c|c|c|c|}
\hline تحدث & سمعى & بصرى & المعلمات & تحدث & سمعى & بصرى & المعلمات \\
\hline$\%$ \% & $\% \circ 9$ & \% YY & $r q$ & \%rr & $\% 04$ & \%rr & 1 \\
\hline \%rr & $\% \circ 9$ & $\% \backslash 1$ & rV & $\% \curlyvee \wedge$ & $\% \circ 9$ & $\% \backslash V$ & $r$ \\
\hline$\%$ rr & $\% \circ 9$ & $\% \backslash V$ & $r \wedge$ & $\% \curlyvee \wedge$ & \%тr & $\%$ IV & $r$ \\
\hline$\%$ rr & \% & $\% \backslash 1$ & rq & \%rr & \%тr & $\% \backslash V$ & $\varepsilon$ \\
\hline \%rr & $\% 7 r$ & $\% 11$ & r. & $\%$ \% & \%тr & $\% \curlyvee \wedge$ & 0 \\
\hline$\%$ rr & \% & $\% \backslash V$ & ו & $\% \curlyvee \wedge$ & \%тr & $\%$ \% & 7 \\
\hline$\%$ rr & $\% \circ 9$ & $\%$ Yr & rr & \%rr & \%тr & $\% \curlyvee \wedge$ & V \\
\hline$\%$ rr & \%тr & $\% \backslash V$ & r & $\%$ \% & $\% \circ 9$ & $\% 11$ & $\wedge$ \\
\hline$\%$ rᄉ & $\% 09$ & $\% 11$ & $r \varepsilon$ & $\% r r$ & \%тr & $\% 11$ & 9 \\
\hline$\%$ rᄉ & \%тr & $\%$ \%^ & ro & $\%$ \% & $\% \circ 9$ & $\% \backslash 1$ & 1. \\
\hline$\%$ rᄉ & $\% \circ 9$ & $\%$ rr & r & $\% \curlyvee \wedge$ & $\% \circ 9$ & $\% 11$ & 11 \\
\hline$\%$ rᄉ & $\%$ & $\%$ \%^ & rV & $\%$ \% & $\% \circ 9$ & $\% \backslash 1$ & $1 \%$ \\
\hline$\%$ rr & \%тr & $\%$ \% & rᄉ & $\%$ \% & \%тr & $\% 11$ & $1 \%$ \\
\hline$\%$ rr & $\% \circ 9$ & $\%$ Yr & rq & $\% \curlyvee \wedge$ & \%тr & $\% 11$ & $1 \varepsilon$ \\
\hline$\%$ rr & $\% \circ 9$ & $\% \backslash V$ & $\varepsilon$. & $\%$ \% & \%тr & $\% \backslash 1$ & 10 \\
\hline \%rr & $\% \circ 9$ & \%rr & \&1 & $\% r r$ & \%тr & $\% \backslash V$ & 17 \\
\hline \%rr & $\% \circ 9$ & \%rr & $\varepsilon r$ & \%rr & \%тr & \%rr & 18 \\
\hline$\%$ rr & $\% 09$ & $\%$ Yr & $\varepsilon r$ & \%rr & $\% \circ 9$ & \%rr & 11 \\
\hline$\%$ rr & \%тr & $\% r r$ & $\varepsilon \varepsilon$ & $\% r r$ & $\% \circ 9$ & $\% 11$ & 19 \\
\hline$\%$ rᄉ & \%тr & $\%$ Yr & $\leqslant 0$ & $\% r r$ & $\% \circ 9$ & $\% \backslash V$ & $r$. \\
\hline$\%$ rr & \% & $\% 11$ & $\leqslant 7$ & $\% \backslash V$ & \%тr & $\% r r$ & YI \\
\hline$\% \backslash \mathrm{V}$ & \%тr & $\% 11$ & $\leq V$ & $\% \backslash V$ & \%тr & $\% r r$ & Yr \\
\hline$\%$ \% & \%тr & $\% \backslash V$ & $\leqslant \Lambda$ & $\% \backslash V$ & \%тr & $\%$ \% & rr \\
\hline$\% \backslash \mathrm{V}$ & \%тr & $\% \backslash V$ & $\leq 9$ & $\% \backslash V$ & \%тr & $\%$ \% & $r \leq$ \\
\hline \%rr & \%тr & $\% \backslash V$ & 0 . & \%rr & $\% 07$ & \%rr & ro \\
\hline
\end{tabular}




\section{يتضح من جدول (V) ما يلي:}

نسب ملاحظة الباحثة على الوسائل المقدمة داخل الروضات جاءت بالترتيب

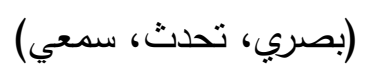

- تراوحت نسب البعد الأول البصري بين 0 -

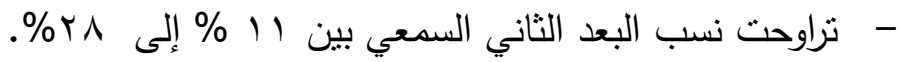

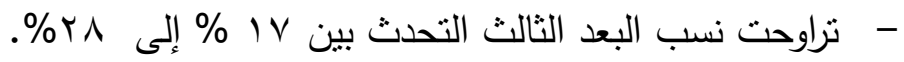

ويفسر ذلك ان توفر الوسائل البصرية كانت اعلى من وسائل التحدث ووسائل

التحدث كانت اعلى من الوسائل السمعية

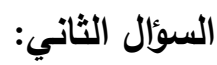

للإجابة عن السؤال الثاني والذي ينص على " ما مدى توافر الأنثطة الصفية التي تستخدمها المعلمة لتنمية مهارات الاستعداد القرائي" ـ تم حساب النسب المئوية، وجدول (^) يوضح ذللك. (^)

جدول(^): النسب المئوية لاستجابات المعلمات على الانشطة الصفية

المتوافرة داخل قاعات الروضة

\begin{tabular}{|c|c|c|c|c|c|c|c|}
\hline تحدث & سمعى & بصرى & المعلمات & تحدث & سمعي & بصرى & المعلمات \\
\hline$\%$ \% & $\% 11$ & $\% T_{1}$ & rq & \%ए। & $\%$ Tr & \% & 1 \\
\hline$\% \curlyvee \wedge$ & $\% r r$ & \% & $r V$ & \%rт & $\% \backslash \vee$ & $\%$ \% & r \\
\hline \%ऍ & $\% \backslash \vee$ & $\%$ \% & rA & \%rт & $\%$ \% & \% & $r$ \\
\hline \%ऑ & $\% \backslash V$ & $\%$ \%४ & rq & \%rт & $\% 11$ & \%rr & $\varepsilon$ \\
\hline \%r & $\% \backslash V$ & $\%$ \%४ & $r$. & \%rt & $\% \backslash V$ & \%rr & 0 \\
\hline \%r & $\% \backslash v$ & \%r। & $r_{1}$ & $\%$ \% & $\% \backslash V$ & $\%$ \%rr & 7 \\
\hline \%ऑ & $\% \backslash V$ & \% & rr & $\%$ & $\% 11$ & \%rr & v \\
\hline \%r & \%rr & \% & rr & \%rr & $\% \backslash V$ & $\%$ \% & $\wedge$ \\
\hline \%r & $\% \backslash V$ & \%r। & $r \varepsilon$ & \%rr & $\% \backslash V$ & \%rr & 9 \\
\hline$\%$ & $\% \backslash V$ & \%फा & ro & \%rт & $\% 11$ & \%rr & 1. \\
\hline
\end{tabular}


مجلة " دراسات في الطفولة والتربية" - جامعة اسيوط

\begin{tabular}{|c|c|c|c|c|c|c|c|}
\hline تحدث & سمعى & بصرى & المعلمات & تحدث & سمعي & بصرى & المعلمات \\
\hline \%ऍ & $\%$ IV & \% & q & \%тч & $\% 11$ & \% ו & 11 \\
\hline \%r & $\%$ IV & \% & $r v$ & \% & $\% 11$ & $\%$ \% & Ir \\
\hline \%ऍ & $\% 11$ & \% & r & \%чч & $\% 11$ & \% & ir \\
\hline سז\% & $\% \backslash V$ & \% & $r q$ & \%rч & $\% 11$ & $\%$ \% & $1 \varepsilon$ \\
\hline \%rq & $\%$ \%r & \% & $\varepsilon$. & $\%$ \% & $\% 11$ & سז\% & 10 \\
\hline \%rч & $\% \backslash V$ & ו ו & \&1 & \% ו & $\% 11$ & سז\% & 17 \\
\hline \%「人 & $\% \backslash V$ & \% ו & $\varepsilon r$ & $\%$ \% & $\%$ IV & \% ו & 18 \\
\hline \%ऍ & $\% \backslash \mathrm{V}$ & سז\% & $\varepsilon r$ & \%rr & $\% 11$ & \%r\% & 11 \\
\hline \%rl & $\% r r$ & \%rr & $\varepsilon \varepsilon$ & \%rr & $\% \backslash V$ & \%זr\% & 19 \\
\hline \%rl & $\% \backslash V$ & سז\% & $\leq 0$ & $\%$ \% & $\%$ rr & \%) & $r$. \\
\hline \%rч & \%rr & \% וس & $\varepsilon 7$ & \% ו & \%rr & سז\% & Y \\
\hline$\%$ ry & $\%$ \% & سז\% & $\varepsilon V$ & $\% \curlyvee \wedge$ & \%rr & \%r। & rr \\
\hline$\%$ ry & $\%$ \% & \% & $\varepsilon \Lambda$ & $\% \curlyvee \wedge$ & $\%$ IV & $\%$ \% & $r r$ \\
\hline \%) & $\%$ IV & \% ו & $\leqslant 9$ & \% ו & $\% 11$ & سז\% & $r \varepsilon$ \\
\hline$\%$ \% & $\% \backslash 1$ & سץ\% & 0. & $\% \curlyvee \wedge$ & $\% \backslash V$ & \% ו & ro \\
\hline
\end{tabular}

نسب استجابات المعلمات على الانشطة المقدمة داخل الروضات جاءت بالترتيب (بصري، تحدث، سمعي)

- تراوحت نسب البعد الأول البصري بين ^r \% إلى بr\%.

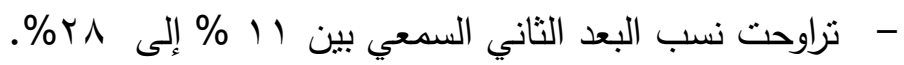

- تراوحت نسب البعد الثالث التحدث بين بr \% إلى بr\%.

وهذا يدل ان تأثثر الانشطة البصرية كانت بصورة افضل من ثأثثر الانشطة السمعية والتحدث. وكذلك انشطة التحدث كانت بصورة افضل من الانشطة السمعية 
للإجابة عن السؤال الثالث والذي ينص على "ما مدى توافر مهارات الاستعداد

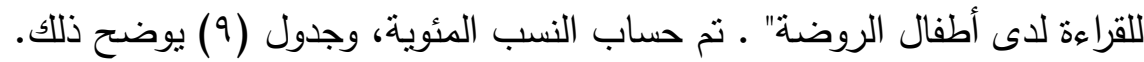

جدول(9): النسب المئوية لاستجابات الأطفال على الاختبار داخل قاعات الروضة

\begin{tabular}{|c|c|c|c|c|c|c|c|}
\hline تحدث & سمعى & بصرى & الأطفال & تحدث & سمعى & بصرى & الأطفال \\
\hline \%) & $\% 1$ & \%ाr & rq & \%) & $\% 1$ & \%) & 1 \\
\hline$\% 1$ & $\% 1$ & \%ाr & $r V$ & $\% 1$. & $\% 1$ & \%ाr & r \\
\hline \%) & $\% 1$ & \%ाr & $r \wedge$ & $\% \wedge$ & $\% 1$. & $\% 1$. & r \\
\hline$\% 1$ & $\% 1$ & \%ाr & rq & $\% 1$. & $\% 1$ & \%) & $\varepsilon$ \\
\hline$\%$ & $\% 1$. & $\% 1$. & $r$. & $\% 0$ & $\% \wedge$ & $\% 1$. & 0 \\
\hline$\%$ & \%) & $\% 1$ & I & $\% \wedge$ & $\% \wedge$ & \%) & 9 \\
\hline \%) & \%) & \%ाr & rr & $\% \wedge$ & $\%$ & \%) & v \\
\hline$\% 0$ & \%) & $\% 1$. & rr & $\% \wedge$ & $\% 1$ & \%וr & $\Lambda$ \\
\hline$\% \wedge$ & \%ाr & \%וr & $r \leq$ & $\% \wedge$ & $\% 1$. & \%וr & 9 \\
\hline$\%$ & $\% 1$ & \%ाr & ro & $\% \wedge$ & $\% 1$ & \%ाr & 1. \\
\hline \%) & $\% 1$. & $\% 1$. & r & $\% 0$ & $\% 1$. & \%וr & 11 \\
\hline$\%$ & $\% 1$. & \%) & $r v$ & $\% 0$ & $\% 1$. & $\%$ & Ir \\
\hline$\% \wedge$ & $\% 1$. & $\% 1$. & $\mu$ & $\% \wedge$ & $\% 1$. & $\% 1$. & Ir \\
\hline$\%$ & $\% 1$ & $\%$ & $m q$ & $\% 1$. & \%וr & $\% 1$ & $1 \leq$ \\
\hline$\%$ & $\% \wedge$ & \%) & $\varepsilon$. & $\% 1$. & $\% \wedge$ & \%) & 10 \\
\hline$\% \wedge$ & $\% \wedge$ & \%ा & $\leq 1$ & $\% 1$. & \%וr & $\% 1$. & 17 \\
\hline$\%$ & \%) & \%) & $\varepsilon r$ & $\% 1$. & $\% 1$. & $\%$ & 18 \\
\hline$\% 1$. & \%) & $\% 1$. & $\varepsilon r$ & $\% 0$ & $\% 1$. & $\% 1$. & 11 \\
\hline$\% 1$. & \%) & \%וr & $\leq \varepsilon$ & $\% 1$. & $\% 1$ & \%וr & 19 \\
\hline$\% 1$. & $\% 1$. & \%וr & $\leq 0$ & $\% 0$ & $\% 1$. & $\% 1$. & $r$. \\
\hline$\% \wedge$ & $\% 1$. & \%) & $\leq 7$ & $\% 0$ & $\% \wedge$ & \%) & r \\
\hline$\% \wedge$ & $\% 1$. & \%וr & $\varepsilon V$ & $\% 1$. & \%וr & \%וr & rr \\
\hline$\% \wedge$ & $\% 1$. & $\% 1$. & $\varepsilon \wedge$ & $\% \wedge$ & \%וr & \%וr & rr \\
\hline$\% \wedge$ & $\% 1$ & \%ाr & $\leq 9$ & $\% \wedge$ & \%וr & \%וr & $r \varepsilon$ \\
\hline$\% \wedge$ & $\% 1$. & \%ाr & 0 . & $\% \wedge$ & $\% \wedge$ & \%ाr & ro \\
\hline
\end{tabular}




\section{مجلة " دراسات في الطقولة والتربية" - جامعة اسيوط}

\section{يتضح من جدول (9) ما يلي:}

نسب استجابات الأطفال على الاختبار داخل الروضات جاءت بالترتيب ( بصري، تحدث، سمعي) (1) - (2) تراوحت نسب البعد الأول البصري بين • ـ \% إلى سا \%\%. تراوحت نسب البعد الثاني السمعي بين ه \% إلى سا \% . تراوحت نسب البعد الثالث التحدث بين ^ \% إلى ؟ با \%.

وتفسير ذلك يرجع الى تتمية المهارات البصرية كانت اعلى بسبب توافر الوسائل والانشطة البصرية وكذلك الوسائل والانشطة السمعية متوفرة بدرجة منخفضة وبالتالي حققت انخفاض في المهارات السمعية بينما وسائل وانشطة التحدث كانت بدرجة منوسطة وبالتالي كانت مهارات التحدث متوسطة عند الاطفال

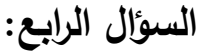

للإجابة عن السؤال الرابع والذي ينص على "ما العلاقة الارتباطية بين بيئة

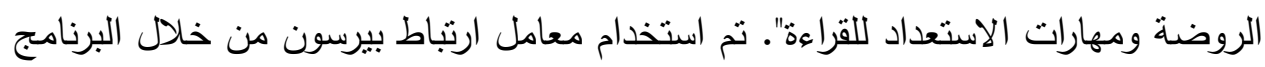
الإحصائي Spss، وجدول (· ( ) يوضح ذلك.

جدول( • 1): مصفوفة معاملات الارتباط بين العمل في بيئة الروضة والذي تمثلة الاستبانة ويطاقة الملاحظة والاختبار المطبق على الاطفال

\begin{tabular}{|c|c|c|c|c|}
\hline \multicolumn{3}{|c|}{ اختبار مهارات الاستعداد للقراعة } & \multirow{2}{*}{ 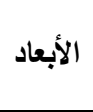 } & \multirow{2}{*}{ بيئة العمل في الروضة } \\
\hline تحدث & سمعي & بصري & & \\
\hline$* *$ *.Vฯ & $* * \cdot . V \leq r$ & $* * . \vee \vee 01$ & بصري & \multirow{3}{*}{ الاستبانة } \\
\hline$* * . . T \wedge V$ & $* *$ *.VTI & 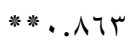 & سمعي & \\
\hline$* * . \vee \vee Y q$ & ***.人тr & $* * \cdot . \wedge \cdot q$ & تحدث & \\
\hline$* * \ldots V Y \leq$ & $* * . \wedge r q$ & $* * \cdot . \vee \cdot q$ & بصري & \multirow{3}{*}{ طاقة الملاحظة } \\
\hline$* * . \vee v$ & $* * . \wedge .9$ & $* * .709$ & سمعي & \\
\hline$* * .71 \mathrm{~V}$ & $* * . . \vee \circ 9$ & $* * . . V V Y$ & تحدث & \\
\hline
\end{tabular}




\section{يتضح من جدول (· (1) ما يلي:}

- توجد علاقة ارتباطية ذات دلالة إحصائية بين الانشطة التي تستخدمها المعلمة

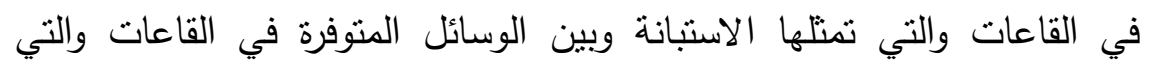
تمثلها بطاقة الملاحظة وبين اختبار مهارات الاستعداد للقراءة المطبق على ولى لهين الأطفال وهذا يؤكد العلاقة الطردية بين بيئة الروضة ومهارات الاستعداد للقراءة

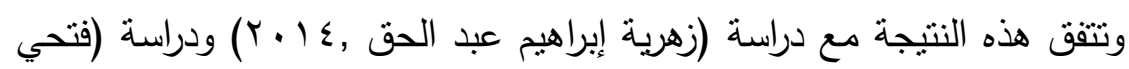

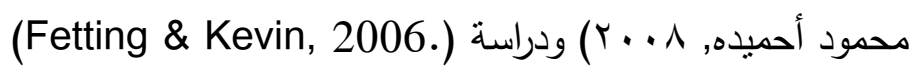
ودراسة (2004 Gayle-Evans توكد هذه الدراسات على اهية بيئة الروضة فى تتمية المهارات والمفاهيم عند الطفل توصيات البحث

- - ضرورة تزويد القاعات بالوسائل والانشطة البصرية التي تساعد الطفل على تتمية

$$
\text { المهارات البصرية }
$$

- - أن تتاسب مواصفات البيئة بالروضة مع خصائص النمو لدى الأطفال. - تتمية وعي المعلمات بمعايير الجودة الخاصة بتجهيزات الروضة المناسبة لجوانب نمو الاطفال.

- - مرورة تزويد القاعات بالوسائل والانشطة التي تساعد الطفل على تتمية مهارات

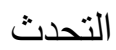

- - ضرورة تزويد القاعات بالوسائل والانشطة السمعية التي تساعد الطفل على تتمية المهارات السمعية - ضرورة تكثيف عملية الأشراف علي معلمات رياض الأطفال وتزويدهن بكل جديد في

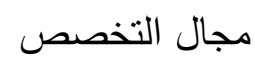
- - توفير قاعات احتياطية بالروضة يمكن استخدامها في الأنثطة المختلفة مع الأطفال. 


\section{مجلة " دراسات في الطقولة والتربية" - جامعة اسيوط}

- - تشجيع معلمات الروضة على التتويع في الانشطة المقدمة للطفل حتى تتحقق الأهداف التربوية له جسمياً وعقلياً وانفعالياً واجنماعياً.

- الاستفادة بجميع المعينات والوسائل والوسائط التعليمية الموجودة بالروضة. - - إعادة النظر في برامج إعداد معلمات رياض الأطفال وتحسينها و التي تمكنها من تتمية العديد من المهارات لدى طفل الروضة. البحوث المقترحة: في ضوء نتائج هذا البحث تقترح الباحثّة إجراء عدد من البحوث والدراسات - - أثز بيئة الروضة على تطور المظاهر النمائية المختلفة للأطفال - - بيئة الروضة المحيطة وعلاقتها ببعض مهارات التفاعل الاجتماعي بين الأطفال. - - استخدام الالعاب التربوية لتتمية بعض المفاهيم اللغوية لاى طفل الروضة 


\section{المراجع}

- - أحلام قطب فرج ( . . . . م). مدى فاعلية طرق استخدام بعض الوسائط التعليمية في تتمية بعض المفاهيم اللغوية للطفل في ضوء أهداف الروضة، رسالة ماجستير غير منشورة، القاهرة جامعة عين شمس، كلية التربية - أحمد عبد الله، فهيم مصطفى ( (... (.م). الطفل ومشكلات القراءة، الطبعة الرابعة، القاهرة: الدار المصرية اللبنانية

- - السيد محمد أبو هاشم (ع . . بم). سيكولوجية المهارات، القاهرة : مكتبة زهراء الثرق. - امال عبد العزيز مسعود(1) ـ (Y):مهارات التواصل لدى طفل الروضة وعلاقتها ببعض

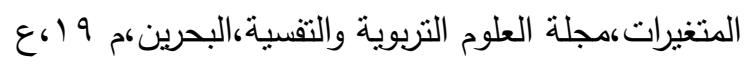
- إيفا ل عيسى (ع . . ب م). مدخل إلى التعليم في الطفولة المبكرة،ترجمة: احمد الثافعي، العين :دار الكتاب الجامعي

- -

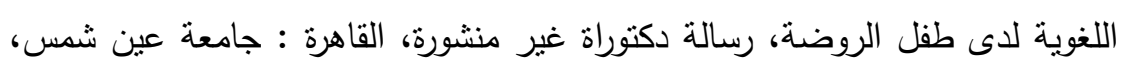
معهد الدراسات العليا للطفولة - - ثناء يوسف الضبع (1 ( . r م). تعلم المفاهيم اللغوية والدينية لدى الأطفال،القاهرة : دار الفكر العربي.

- - جميل طارق عبد المجيد (0. . rم).إعداد الطفل العربي للقراءة والكتابة، عمان: دار صفاء للطباعة والنشر والتوزيع.

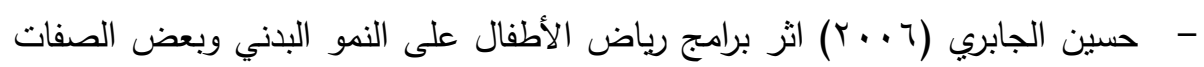

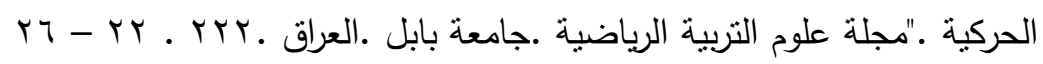

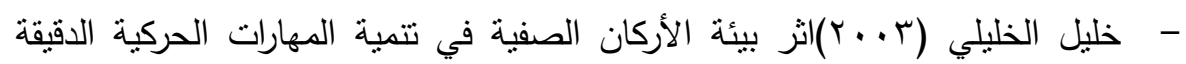
لطفل الروضة ."مجلة الطفولة العربية - رانية صاصيلا ( • ( • ) استراتيجية مقترحة لتطوير نظام إعداد معلم رياض الأطفال

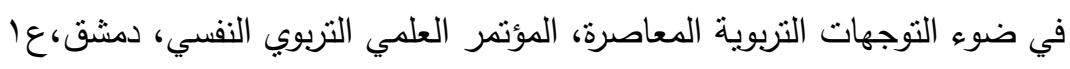




\section{مجلة " دراسات في الطقولة والتربية" - جامعة اسيوط}

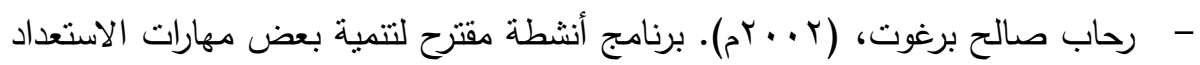
للقراءة والكتابة للأطفال ذوي صعوبات التعلم بمرحلة رياض الأطفال، رسالة دكتوراة غير منشورة، القاهرة : جامعة عين شمس، معهد الدراسات العليا للطفولة. - - زهرية إبراهيم عبد الحق (ع ( ب) أثز بيئة الأركان التعليمية في تتمية التفكيرالإبداعي

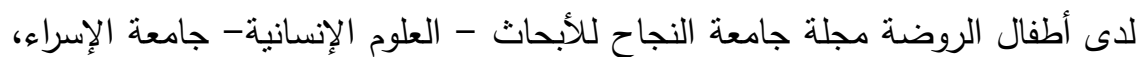
الأردن

- سعد الثريع وامال الغربللي (1 (ب): .دور مبنى الروضة في تفعيل أنشطنها .حولية

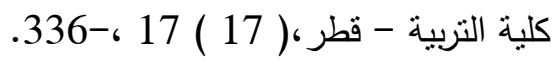

- سعد عبد الرحمن، إيمان محمد (r . .rم). الاستعداد لتعلم القراءة تتميته وقياسه في

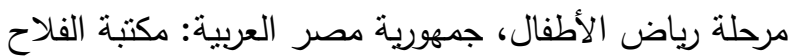

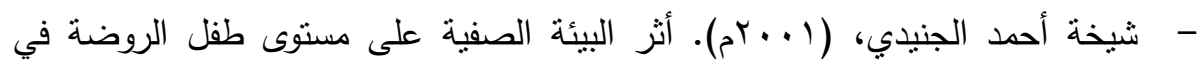
الرسم،وقدرته اللغوية في التعبير عما يرسم، والزمن الذي يقضيه في ممارستههوعدد الرسوم التي ينجزها، رسالة ماجستير غير منشورة، بيروت: جامعة القديس يوسف، كلية

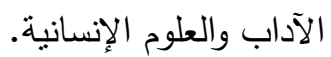

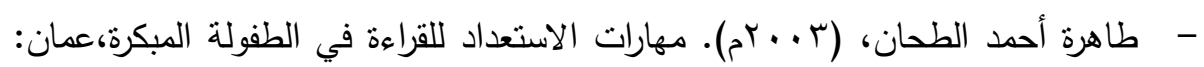
دار الفكر للطباعة والنشر.

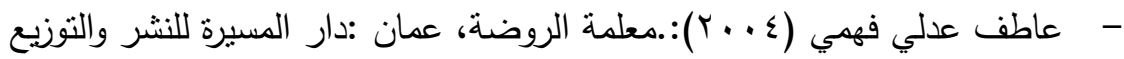

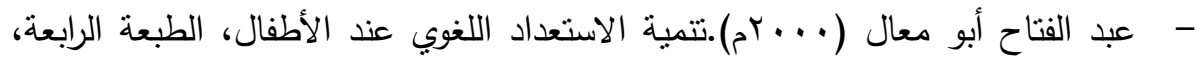
عمان: دار الثنروق للنشر والتوزيع.

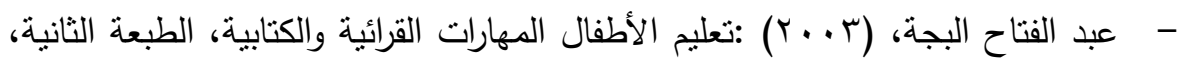

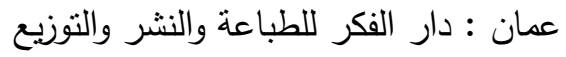
- عبد اللطيف حسين فرج (0. . بم). تعليم الأطفال والصفوف الأولية الطبعة الأولى، عمان: دار المسيرة للنشر والتوزيع.

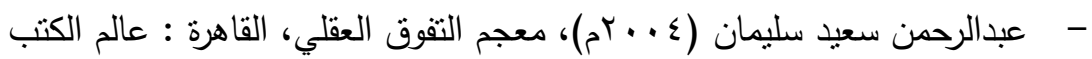


- - عبدالرحيم صالح عبد اله (ץ . - آم). تعليم اللغة في منهج تربية الطفولة المبكرة في

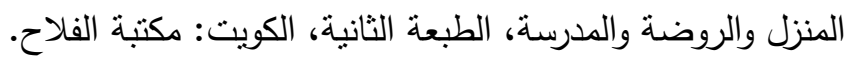

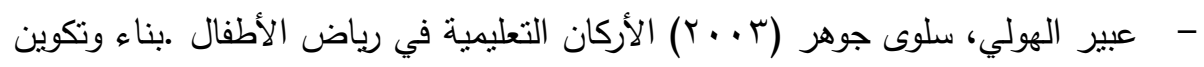
شخصية الطفل .دار الكتاب الحديث .القاهرة.

- علي الحبيب (9901م). التربية واستراتيجياتها في رياض الأطفال , الكويت : ذات

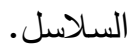

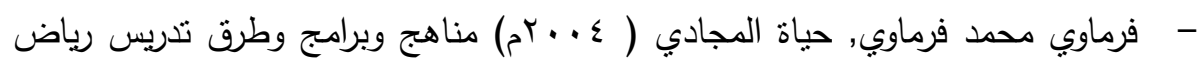

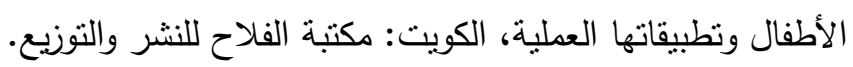

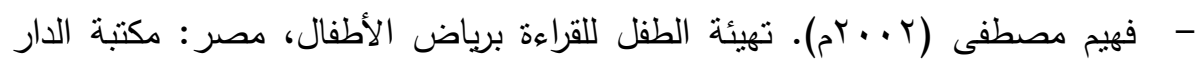
العربية للكتاب.

- فوقية حسن رضوان، (·. - (بم). كيف نعد طفل الروضة لتعلم القراءة، القاهرة :دار الانجلو المصرية. - كريمان بدير، ايميلي صادق (...بم). تتمية المهارات اللغوية للطفل،القاهرة: عالم الكتب للطباعة والنشر والتوزيع. بئ.

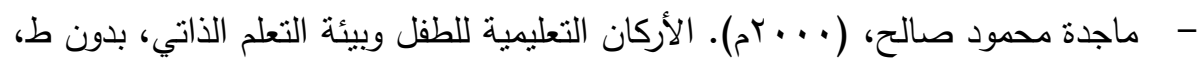
الإسكندرية: المكتب العلمي للنشر والتوزيع.

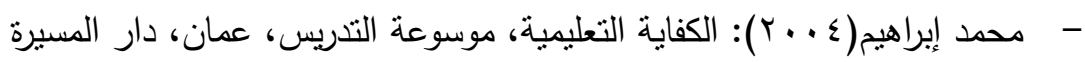

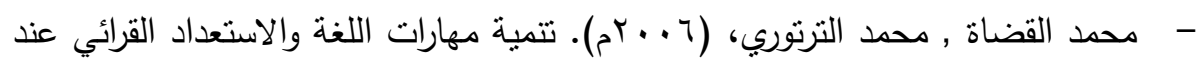
طفل الروضة، عمان : دار الحامد للنشر والتوزيع. - محد عبد الرحبم عدس (1 ...rم). مدخل الى رياض الأطفال، عمان: دار

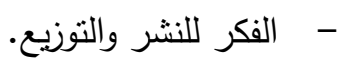
- نايف سليمان، وآخرون ( (. . ام).أساليب تعليم الأطفال القراءة والكتابة، الطبعة الأولى، عمان : دار صفاء للنشر والتوزيع. 


\section{مجلة " دراسات في الطقولة والتربية" - جامعة اسيوط}

- - نبيل عبد الهادي، فاتن الصاحب، (r + .rم).سيكولوجية الطفولة في الحضانات ورياض

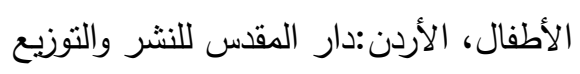

- نجوى بدر خضر (1997) قياس الاستعداد للقراءة لدى الأطفال من عمر (0-7) سنوات، رسالة ماجستير غير منشورة، دمثق: جامعة دمشق، - كلية التربية. -

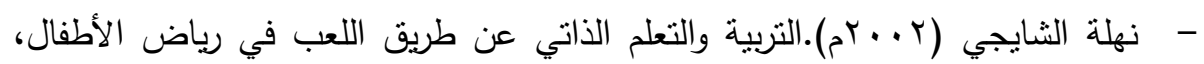
الكويت : مكتبة الربيعان.

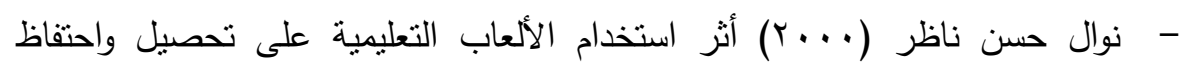

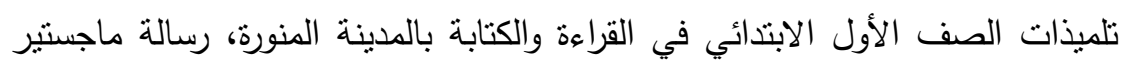
غير منشورة، المدينة المنورة :جامعة الملك عبد العزيز ، كلية التربية.

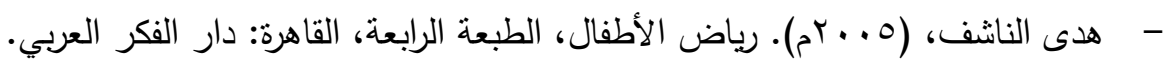
- - هدى قناوي، مضاوى الراثد،، ابتهاج محمد (0...rم). مدخل الى رياض الأطفال،

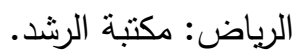

- - هدى محدد قناوي ( (..rم). الطفل ورياض الأطفال، الطبعة الثانية،القاهرة : مكتبة

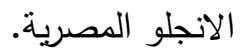

- - هشام الحسن (....ب).طرق تعليم الأطفال القراءة والكتابة، عمان: الدار العلمية

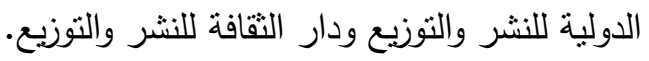

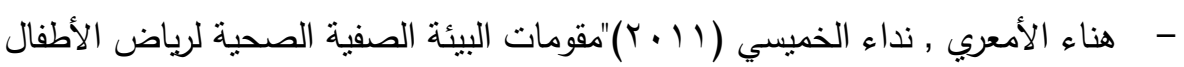

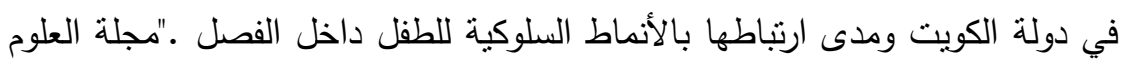

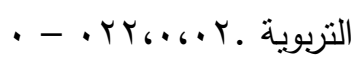

- - هند ماجد الختيلة (.... م م). إدارة رياض الأطفال، الإمارات العربية المتحدة: دار الكتاب الجامعي.

- . AL-Ameel, Huda (2002). The effect of different types of preschool curriculum on Some aspects of children's experience and development in Saudi Arabia, Doctoral degree dissertation, Cardiff University, England.

- Dodge ,Diana Trister et al (2002). The Creative Curriculum for preschool (Fourth edition), Washington .DC: Teaching strategies 
- Elsea,Becky(2001). Increasing student's reading readiness -skills through the use of a balanced literacy program, Master degree Thesis, Saint Xavier University .ED 454505

- Fetting, M. \& Kevin, K. (2006). Should all children attend preschool?. NEA Today; 24(7), 44 .Fuchs ,Douglas(2001). K-PALS :Helping kindergarteners -with reading readiness, Teaching Exceptional

- Gayle-Evans, G. (2004). It is never too soon: A study of kindergarten teachers' implementation of multicultural education in Florida's classrooms. Professional Educator, 26(2), 1-15. Retrieved: De30,2014from: http://files.eric.ed.gov/fulltext/EJ728471.pdf

- Ingraham, p. (1993). "Creating and Managing Learning -Centers: A thematic Approach. NH: Crystal Springs Books

- -Macdonald,G.wayne.Cornwall,Ann(1995)."The relationship between phonological awareness and reading and spelling achievement eleven years later".Jornal of learning disabilities,28(8),pp 523-527.

- Morrow, L. \& McGee, L. (2005). Teaching literacy in kindergarten London: Falmer Press.

- -Morrow, L. \& Rand, M. (1991). "Promoting literacy during play by designing early childhood environment". The Reading of Teacher, 44 (6), 396-402

- Pullen,Paige C. Justic , Laura M ( 2003)." Enhancin -phonological awareness ,print awareness,and,oral language skills in preschool children", Intervention in school and clinic ,(39)2,pp 87-98.

- Children,33(4),pp76-88 Teisel,James et al(2001)." The Utility of kindergarten teacher ratings for predicting low academic achievement in first grade",Jornal of learning disabilities,34(3),pp 286-293

- U.S Department of education (2001).Reading: Know what -works. A practical guide for educators, Washington DC :National inct. For literacy. ED 448

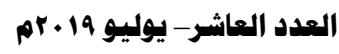

